OECD Working Papers on Public Governance No. 20

\title{
Manual: Public Finance and Employment Database
}

\section{Dirk-Jan Kraan,}

Alessandro Lupi, Emmanuel Job 



\section{(2)) OECD}

BETTER POLICIES FOR BEITER LIVES

\section{MANUAL: \\ PUBLIC FINANCE AND EMPLOYMENT \\ DATABASE}

May 2012 
COECD, May 2012

Dirk Kraan, Alessandro Lupi, Emmanuel Job 


\section{Contents}

Chapter 1 Purpose and contents of the database 5

$\begin{array}{lll}\text { Chapter } 2 \text { COFOG-Special classification } & 7\end{array}$

$\begin{array}{lll}\text { Chapter } 3 \text { Methodology of the database } & 9\end{array}$

$\begin{array}{ll}\text { References } & 17\end{array}$

Annex I Methods used to construct the COFOG-Special expenditure tables 18

Annex II Methods used to construct the revenue tables 24

Annex III Distribution of (sub-)sector employment over COFOG-Special groups 25

Annex IV Complete PFED tables for Estonia 31

Annex V Classification of expenses by function of government 41 


\section{Collective goods in kind}

1. General governance services

2. Basic research

3. Defence

4. Public order and safety

5. Infrastructure and spatial development

6. Market regulation

\section{Collective goods in cash}

7. International co-operation

8. General purpose and block grants

9. Interest

\section{Individual goods in kind}

10. Non-market recreation, culture and religion

11. Social services

12. Health

13. Education

14. Market subsidies

\section{Individual goods in cash}

15. Social cash transfers 


\section{CHAPTER 1 \\ Purpose and contents of the Database}

\section{History and purpose of the database}

1. Over the past seven years the Budgeting and Public Expenditures Division of the Directorate of Public Governance and Territorial Development of the OECD has developed a database of public expenditures according to spending purpose. The classification used resembles closely the international COFOG classification and is therefore called "COFOG-Special". However, the main feature of the classification is that it distinguishes between monetary transfers and expenditures on goods ${ }^{1}$ in kind and between expenditures on collective goods and expenditures on individual goods ${ }^{2}$. The database includes general government and all sub-sectors (central government, states, local government and social security)

2. In addition, as from 2007 a new approach has been developed for the estimation of employment in the public domain as part of work programme of the Public Employment and Management Working Party (PEMWP) of the Public Governance Committee. The PEMWP had been working on estimates of public employment for many years, but the methods used were generally not consistent with the definitions and classifications of the National Accounts. The new approach is consistent with the National Accounts ${ }^{3}$.

3. In 2007 the expenditure database and the employment database were merged. The COFOG-Special classification was maintained and used for both the expenditures and employment part of the database. In this exercise the database was also extended with revenues data. Special care was given to the internal consistency of the database. The merged database was renamed: Public Finance and Employment Database (PFED).

4. For employment data the PFED uses the public sector employment data from the International Labour Organisation (ILO) Laborsta. These data were in theory consistent with the National Accounts, but until 2010 there were in practice discrepancies for many countries. In 2010, the ILO and the OECD decided to join forces and to start a common work programme with the aim of making the Laborsta data entirely consistent with the National Accounts. For this purpose a methodological questionnaire was sent out to all ILO and OECD Member States in the autumn of 2010, in order to collect meta-data on the numbers that were provided to Laborsta and to check consistency with the National Accounts. On the basis of this information, ILO and OECD have compiled a revised employment data collection questionnaire that is sent out in June 2011 to all Members States of ILO and OECD. The data collected by this questionnaire (to be inserted in Laborsta) is entirely consistent with the National Accounts and is the source of the employment data currently available in the PFED.

5. The purpose of the database is that it will serve as a research tool for future OECD work. The database will also be published on line so that it can be used by the worldwide research community.

1 For the sake of simplicity the term "goods" will be used in this Manual in every instance where the National Accounts use "goods and services".

2 A working paper on a previous version, called "COFOG-Special, Working paper on test procedure for five European countries" (BUD, 2007b) was produced in July 2007. Earlier versions were published in the Reallocation report (OECD, 2005) and in the Working Paper Modified COFOG and Mode of Production classifications (BUD, 2007a).

3 This work was reported in the papers "Employment in government in the perspective of the production costs of goods and services in the public domain" (Pilichowski and Turkisch, 2008a) and "The State of the Public Service in OECD countries" (Pilichowski and Turkisch, 2008b). 
6. The present manual describes the contents of the PFED (next section of this chapter), explains the COFOGSpecial classification (chapter 2) and contains an exhaustive treatment of the methodology of the database (chapter 3). Annex I summarizes the methodology of the expenditure part of PFED. Annex II summarizes the methodology of the revenue part of the PFED. Annex III provides some details of the employment estimation method used for countries that were not (yet) able to provide employment data by (regular) COFOG. Annex IV provides all the source tables for the case of Estonia. Annex V provides the regular COFOG classification $1^{\text {st }}$ and $2^{\text {nd }}$ level.

\section{Contents of the database}

7. The database will consists of country tables, subdivided by the sub-sectors of government:
a. General government; which is composed of the sub-sectors:
b. Central government;
c. States ${ }^{4}$;
d. Local government;
e. Social security ${ }^{5}$.

8. Each country level of government will contain three source tables:

1. Expenditures by COFOG-Special groups;

2. Employment by COFOG-Special groups;

3. Revenues.

9. In total this will amount to $5 \times 3=15$ source tables for each federal country and $4 \times 3=12$ source tables for each unitary country. Apart from that, Norway and United Kingdom do not have a social security sector. For that reason these two countries will have $3 \times 3=9$ source tables. This manual will not contain cross-country comparisons, nor presentations in other ways (for instance graphical), nor interpretations, nor forms of secondary analysis. This will be done in subsequent work.

10. On 1 April 2012 the database includes the following 18 OECD countries: Austria, Czech Republic, Denmark, Estonia, Finland, Germany, Greece, Hungary, Ireland, Italy, Luxembourg, Norway, Poland, Portugal, Slovenia, Spain, Sweden, and the United Kingdom. The decisive factor for inclusion in the database is the availability of statistical data from international databases, notably: OECD, Eurostat (the statistical database of the EU) and Laborsta.

4 The state sub-sector will only occur in federal countries (consistent with the National Accounts).

5 The Social Security sub-sector will be presented only for countries that provide information on this subsector of government. There can be two reasons why countries do not provide this information: first, a country may not have social insurance funds (social security benefits may be entirely financed from the budgets of central government, states or local governments), second, a country may choose to provide social insurance data consolidated with the expenditure and revenue data of central government, states and local government (which is allowed by the guidelines for the National Accounts, SNA 1993 par. 4.1112). 


\section{CHAPTER 2 COFOG-Special classification}

\section{The background and structure of the COFOG-Special classification}

11. The National Accounts include a classification of government expenditures in terms of Functions Of Government (COFOG) next to the economic classification. COFOG does not make certain distinctions that are important for public finance analysts as well as for budget practitioners, namely the distinctions between monetary transfers, further to be called transfers "in cash", and goods in kind, and between individual and collective goods. The two splits are at the core of public finance theory and facilitate empirical work inspired by theoretical considerations. In this light BUD has developed a "COFOG-Special" classification that does make these distinctions in addition to the ones of regular COFOG.

12. In public finance theory a division is made between three tasks of public finance: the allocative task, the distributive task and the stabilization task (Musgrave 1959). The allocative task is most efficiently performed by the funding of goods in kind, the distributive task under some conditions by funding of goods in kind and under other conditions by the funding of transfers in cash. In particular, transfers in cash are often more efficient than goods in kind for distributive purposes because they do not constrain the spending choice of the beneficiary. From an analytical perspective the split between goods in kind and transfers in cash is therefore of considerable importance.

13. The split between individual and collective goods is equally of considerable importance from a theoretical point of view. One can think for instance of the propositions that individual goods can in principle be allocated in an optimal way on the basis of marginal cost pricing whereas collective goods cannot.

14. In public finance theory various definitions of collective and individual goods have been proposed. One approach equals a collective good with a "public good" as defined by Samuelson. A collective good in this sense is a good that can be used by additional users without additional costs (zero marginal costs). Musgrave has proposed a similar definition but he uses an additional criterion: non-excludability next to zero marginal costs. The nonexcludability criterion can be conceived in two ways: (1) it may be impossible to bar access (think of wild life conservation or defence); (2) the government may allow free access, although in principle access could be barred (think of toll roads).

15. The PFED uses only the non-excludability criterion (not the zero marginal cost criterion ${ }^{6}$ ) and it uses nonexcludability in the sense of factual non-exclusion, not as impossibility of exclusion (publicly funded roads are collective goods, although access could be barred). In principle this approach implies that the government can decide on the collective or individual character of certain goods (by barring access if that is possible). However, in order to maintain international comparability, a pragmatic approach is followed in this respect: mostly publicly funded goods that are freely accessible according to normal practice in most OECD countries are considered as collective, even if (parts of) them are not freely accessible in some OECD countries (publicly funded toll roads are thus considered as collective goods). The SNA follows the same approach ${ }^{7}$. In practice the PFED has followed the SNA split and is fully consistent with the SNA in this respect.

16. In spite of the theoretical relevance, empirical data that make these splits are lacking. Therefore papers based on public finance theory often have to work with data that are not entirely suitable. COFOG-Special is meant to bridge the gap.

6 The zero marginal cost criterion is a theoretical border criterion, for instance: infrastructure has non-zero maintenance costs, a district court has non-zero marginal costs of additional district population, etc. Hence this criterion is not convenient for empirical application.

7 System of National Accounts 1993 par. 9.42 and 9.43. 
1. Collective goods

A. in kind

B. in cash

2. Individual goods
A. in kind
B. in cash

17. Perhaps even more important than the theoretical considerations is that the mentioned splits are highly relevant from a practical point of view. Budget practitioners are interested in international comparison of expenditure patterns along these lines. The splits are relevant in practical discussions about reallocation of resources and structural reform (decentralisation, pricing of public services, outsourcing, privatization, the role of the private non-profit sector in the provision of public services, etc.).

\section{Sources for the generation of COFOG-Special expenditure and employment data}

18. The main source of COFOG-Special expenditure data is regular COFOG expenditure data. Regular COFOG consists of two levels. The $1^{\text {st }}$ level COFOG splits government expenditure since the 2001 revision in ten groups ${ }^{8}$. The $2^{\text {nd }}$ level COFOG splits each first level group in maximal 9 sub-groups. The regular COFOG classification is shown in annex V. The PFED makes use of both $1^{\text {st }}$ level and $2^{\text {nd }}$ level regular COFOG data ${ }^{9}$.

19. For EU Member countries of the OECD these data are taken over from Eurostat. For this purpose use is made of Eurostat table 11, which provides a cross classification of $2^{\text {nd }}$ level (regular) COFOG and the Economic classification for general government expenditures and its sub-sectors.

20. Not all OECD members are EU members. Efforts are under way to reach agreement with non-EU countries about submission of these data to the OECD, but so far these data have not been delivered. Until non-EU OECD countries will start to deliver these data, the PFED cannot provide data for these countries.

21. Employment numbers for sub-sectors and $1^{\text {st }}$ level COFOG groups are provided by the Laborsta database of the ILO. Employment numbers for $2^{\text {nd }}$ level COFOG groups are not available in Laborsta and are estimated with the use of expenditure data.

8 Regular COFOG has been thoroughly revised by the United Nations in 2001.

9 Until $20052^{\text {nd }}$ level COFOG data were available in some national statistical offices, but were not collected by international organisations. Moreover, the $2^{\text {nd }}$ level COFOG data were not well comparable between countries because the System of National Accounts (SNA93) and the Government Finance Statistics Manual (IMF, 2001) do not provide much practical information on the application of the COFOG concepts. However, in 2005 Eurostat has established a task force that has developed a manual on the application of COFOG (Eurostat, 2007) to national accounts expenditure data and that has enabled to collect first and second level COFOG data for European countries. Most EU countries, DG ECFIN of the EU, the Workgroup on the Quality of Public Finance of the EU, the OECD and the European Central Bank, participate in this task force. 


\section{CHAPTER 3 \\ Methodology of the database}

\section{Expenditures by COFOG-Special groups}

22. The COFOG-Special classification is characterised by two splits that do not occur in regular COFOG: (1) the cash/in kind split, and (2) the collective/individual good split. This COFOG-Special classification is applied in the first place to the expenditures of government. Subsequently, the COFOG-Special classification is applied to employment on the basis of the same methodology. The two splits on expenditures are explained below.

23. In order to make the two splits at the level of COFOG-Special groups, $2^{\text {nd }}$ level (regular) COFOG data are required. These data are available for general government for all countries included in the PFED. However, for some countries $2^{\text {nd }}$ level COFOG data are not yet available for the subsectors of general government. In these cases estimations will be used for the subsectors.

\section{The split between transfers in cash and goods in kind}

24. According to the economic classification of the National Accounts government expenditures can be divided into expenditures for:

- Compensation of employees,

- Intermediate consumption, Other taxes on production, Current taxes on income, Wealth etc., and Adjustment for the change in net equity of households in pension funds (further to be called: Intermediate consumption etc.),

- Gross capital formation and acquisitions less disposal of non- financial non-produced assets (further to be called: Gross capital formation etc.),

- Property income,

- Other current transfers,

- Capital transfers,

- Subsidies,

- Social benefits other than social transfers in kind and Social transfers in kind (via market producers), in this manual further to be called: Social benefits ${ }^{10}$.

25. The split of the PFED between transfers in cash and goods in kind is based on this division in the National Accounts. Transfers in cash comprise a part of Property income, a part of Other current transfers, a part of Capital transfers and a part of Social security benefits. Goods in kind comprise expenditures for Compensation of employees, Intermediate consumption etc., Gross capital formation etc., Subsidies, and the remaining parts of Property income, Other current transfers, Capital transfers and Social security benefits.

26. Expenditures for Compensation of employees, Intermediate consumption etc., Gross capital formations etc. are used for goods in kind per definition. The part of Property income which is treated as transfers in cash consists of interest payments. They are treated as transfers in cash because the acquired capital, on which the interest is due, is part of the general revenue fund of the government and not earmarked for a specific use. The part of Other current transfers and Capital transfers which are treated as transfers in cash consists of non-earmarked grants to other subsectors of government or other sectors. The remaining parts of property income, other current transfers and capital transfers are treated as expenditures for goods in kind because they are earmarked for a specific use. All Social

10 To the in kind part of Social benefits (in the sense of the national accounts) also belong Transfers of individual non-market goods or services (D632). These are transfers other than those granted under social security or social assistance arrangements, for instance for education. 
benefits other than social transfers in kind are treated as transfers in cash because they are not earmarked for specific use. Subsidies are treated as goods in kind because they are per definition earmarked for a specific use.

\section{The split between individual and collective goods}

27. The split between expenditures for individual and collective goods builds forth on the split between individual and collective Final consumption expenditures in the National Accounts. By convention, in the National Accounts Final consumption expenditures are considered as individual if the relevant flows belong to the following $2^{\text {nd }}$ level COFOG groups:

(a) 7.1 Medical products, appliances and equipment

7.2 Outpatient services

7.3 Hospital services

7.4 Public health services

(b) 8.1 Recreational and sporting services

8.2 Cultural services

(c) 9.1 Pre-primary and primary education

9.2 Secondary education

9.3 Post-secondary non-tertiary education

9.4 Tertiary education

9.5 Education not definable by level

9.6 Subsidiary services to education

(d) 10.1 Sickness and disability

10.1 Old age

10.2 Survivors

10.3 Family and children

10.4 Unemployment

10.5 Housing

10.6 Social exclusion not elsewhere classified.

28. Accordingly, Compensation of employees and Intermediate consumption etc. and Social transfers in kind (via market producers) which make up the largest part of Final consumption expenditures are considered as individual if they belong to the above mentioned $2^{\text {nd }}$ level groups.

29. In the National Accounts no split is available for Gross capital formation etc., Property income, Other current transfers, Capital transfers, Subsidies and Social benefits other than social transfers in kind ${ }^{11}$. Following the split of final consumption expenditures, the split of these flows is made in the same way: flows belonging to the $2^{\text {nd }}$ level COFOG groups mentioned in par. 27 are considered as individual, the remaining flows as collective.

11 Social transfers in kind corresponding to purchases of products supplied to households via market producers are included in Final consumption expenditures. Social benefits other than social transfers in kind are not and thus not split in individual and collective. 
30. Cash transfers for collective goods are split among COFOG-Special groups as follows:

a. International co-operation consists of Other current transfers and Capital transfers in $2^{\text {nd }}$ level COFOG groups Executive and legislative organs, financial and fiscal affairs, external affairs ${ }^{12}$ and Foreign aid ${ }^{13}$.

b. General purpose and block grants ${ }^{14}$ consists of Other current transfers and Capital transfers in $2^{\text {nd }}$ level COFOG group Transfers of a general character between different levels of government ${ }^{15}$.

c. Interest consists of Property income in the $2^{\text {nd }}$ level COFOG group Public Debt transactions.

31. If for certain countries $2^{\text {nd }}$ level COFOG groups are not available for sub-sectors, estimations have been made to identify the transfers in cash groups International co-operation, General purpose and block grants and Interest ${ }^{16}$. These estimations are the following:

- International co-operation: it is assumed that Other current transfers and Capital transfers in $2^{\text {nd }}$ level COFOG groups Executive and legislative organs, financial and fiscal affairs, external affairs and Foreign aid only exists at the level of central government, so that the general government number can be attributed to central government. Accordingly International co-operation at the sub-sectors of states, local government and social security are assumed to be zero.

- General purpose and block grants: it is assumed that apart from the (imputed) Other current transfers and Capital transfers in $2^{\text {nd }}$ level COFOG groups Basic research, Executive and legislative organs, financial and fiscal affairs, external affairs and Foreign economic aid ${ }^{17}$, there exist no Other current transfers and no Capital transfers in $1^{\text {st }}$ level COFOG group General public services than those in $2^{\text {nd }}$ level COFOG group Transfers of a general character between different levels of government. Accordingly, all Other current transfers and Capital transfers in the $1^{\text {st }}$ level COFOG group General Public Services except the (imputed) Other current transfers and Capital transfers on Basic research, Executive and legislative organs, financial and fiscal affairs, external affairs and Foreign economic aid are identified as General purpose and block grants.

- Interest: it is assumed that apart from the (imputed) Property income in $2^{\text {nd }}$ level COFOG group Basic Research ${ }^{18}$ there exist no other Property income expenditures in the $1^{\text {st }}$ level COFOG group General public services than those in $2^{\text {nd }}$ level COFOG group Public debt transactions. Accordingly, all Property income in the $1^{\text {st }}$ level COFOG group General Public Services except the (imputed) Property income in $2^{\text {nd }}$ level COFOG group Basic Research is identified as Interest.

12 These transfers mainly consist of contributions to international organisations.

13 These transfers consist of development aid.

14 In general government, the transfers between levels of government are consolidated and thus eliminated from the data. This implies that at the level of general government the group General purpose and block grants cannot occur.

15 All Other current transfers and Capital transfers in other COFOG groups, except those in the $2^{\text {nd }}$ level groups Executive and legislative organs, financial and fiscal affairs, external affairs and Foreign aid (see under a) are considered as in kind because they are earmarked contributions.

16 The estimations methods have been tested for some countries for which $2^{\text {nd }}$ level COFOG data were available and turned out to be acceptable.

17 Remember that if $2^{\text {nd }}$ level COFOG data for sub-sectors are lacking, all Other current transfers and Capital transfers on Executive and legislative organs, financial and fiscal affairs, external affairs and on Foreign economic aid of General government are attributed to Central government (see under first bullet). The same is true for all expenditures on Basic research (see par. 34 below).

18 Note that if $2^{\text {nd }}$ level COFOG data for sub-sectors are lacking, all expenditures of General government on Basic research are attributed to central government (see par. 34 below). 
32. Social cash transfers consist of Social benefits other than transfers in kind in $1^{\text {st }}$ level COFOG group Social protection. However, since the split of Social benefits in (a) social benefits other than social transfers in kind (= cash; D 62), and (b) social transfers in kind (= in kind, D6311_D63121_D63131) is not available by COFOG groups, an additional estimation is required to identify the cash group Social cash transfers. It is assumed that all Social benefits in $1^{\text {st }}$ level COFOG group Social protection are cash expenditures ${ }^{19}$. All other flows in $1^{\text {st }}$ level COFOG group Social protection are in kind. It deserves attention that this assumption implies that the distinction between Social Services and Social cash transfers in COFOG-Special does not entirely coincide with the distinction between social benefits other than social transfers in kind, and social transfers in kind of the economic classification.

\section{The distribution of collective goods in kind among COFOG-Special groups}

33. Expenditures for collective goods in kind are split among COFOG-Special groups as follows:

a. General governance services consists of all expenditures minus Subsidies in $1^{\text {st }}$ level COFOG group General public services, and minus: (a) the (imputed) expenditures in $2^{\text {nd }}$ level COFOG group Basic Research, (b) Other current and Capital transfers in $2^{\text {nd }}$ level COFOG groups Executive and legislative organs, financial and fiscal affairs, external affairs, Foreign aid and Transfers of a general character between different levels of government, and (c) Property income in $2^{\text {nd }}$ level COFOG group Public debt transactions.

b. Basic research consists of all expenditures minus Subsidies in $2^{\text {nd }}$ level COFOG group Basic research of $1^{\text {st }}$ level COFOG group General public services.

c. Defence consist of all expenditures minus Subsidies in $1^{\text {st }}$ level COFOG group Defence.

d. Public order and safety consist of all expenditures minus Subsidies in $1^{\text {st }}$ level COFOG group Public order and safety.

e. Infrastructure and spatial development consists of all expenditures minus Subsidies in $2^{\text {nd }}$ level COFOG groups Transport and Communication of $1^{\text {st }}$ level COFOG group Economic Affairs and in the $1^{\text {st }}$ level COFOG group Housing and community amenities.

f. Market regulation: consists of all expenditures minus Subsidies in (a) $2^{\text {nd }}$ level COFOG groups General economic, commercial and labour affairs, Agriculture, forestry, fishing and hunting, Fuel and energy, Mining, manufacturing and construction, Other industries, Research and development economic affairs, and Economic affairs not elsewhere classified of $1^{\text {st }}$ level COFOG group Economic Affairs, (b) $2^{\text {nd }}$ level COFOG groups Broadcasting and publishing services, Religious and other community services, Research and development recreation, culture and religion and Recreation, culture and religion not elsewhere classified of $1^{\text {st }}$ level COFOG group Recreation, culture and religion, (c) $2^{\text {nd }}$ level COFOG groups Research and development Education and Education not elsewhere classified of $1^{\text {st }}$ level COFOG group Education, (d) $2^{\text {nd }}$ level COFOG groups Research and development Health and Health not elsewhere classified of $1^{\text {st }}$ level COFOG group Health, (e) $2^{\text {nd }}$ level COFOG groups Research and development Social protection and Social protection not elsewhere classified of $1^{\text {st }}$ level COFOG group Social protection ${ }^{20}$ and (f) $1^{\text {st }}$ level COFOG group Environmental protection.

34. If for certain countries $2^{\text {nd }}$ level COFOG groups are not available for sub-sectors, estimations are made to identify the expenditures for Basic research and for Market regulation. These estimations are the following:

19 The assumption was tested for five countries (Australia, Denmark, Germany, Japan and Korea) and turned out to be acceptable.

20 If there are any Social benefits in $2^{\text {nd }}$ level COFOG groups Research and development Social protection and Social Protection not elsewhere classified they are excluded from Market regulation in connection with the estimation procedure of Social cash transfers (see par. 32). 
- Basic research: it is assumed that Basic research only exists in central government, so that the General government number can be attributed to Central government ${ }^{21}$. Accordingly, Basic research at the subsectors of states, local government and social security is assumed to be zero.

- Market regulation: it is assumed that the proportion of Market regulation in $1^{\text {st }}$ level COFOG groups (a) Economic affairs, (b) Recreation, culture and religion, (c) Health, (d) Education and (e) Social protection is identical in all sub-sectors to the proportion of Market regulation in these $1^{\text {st }}$ level COFOG groups in General government.

\section{The distribution of individual goods in kind among COFOG-Special groups}

35. Expenditures for individual goods in kind are split among COFOG-Special groups as follows:

a. Non-market recreation, culture and religion consist of all expenditures minus Subsidies and minus expenditures attributed to Market regulation in $1^{\text {st }}$ level COFOG group Recreation, culture and religion.

b. Social services consists of all expenditures minus Subsidies, minus Social benefits and minus expenditures attributed to Market regulation in $1^{\text {st }}$ level COFOG group Social protection.

c. Health consists of all expenditures minus Subsidies and minus expenditures attributed to Market regulation in the $1^{\text {st }}$ level COFOG group Health.

d. Education consists of all expenditures minus Subsidies and minus expenditures attributed to Market regulation in the $1^{\text {st }}$ level COFOG group Education.

e. Market subsidies consist of all expenditures for subsidies in all $1^{\text {st }}$ level COFOG groups.

36. The split described in par. 35 under e. implies that subsidies in all COFOG groups are always considered as expenditures for individual goods. The reasons are twofold. First, subsidies in these groups are used to finance individual goods (think of environmental subsidies, public transport subsidies, subsidies to keep uncompetitive industries alive, etc.). One could reason that what these transfers are subsidising is the external or redistributive effect, not the individual good itself; the external or redistributive effect is collective. However, this is true for all goods that the SNA defines as individual (most expenditures for health, education, social protection). In all these cases the reason for public funding is the external or redistributive effect. Nevertheless these goods are defined as individual, because what counts is the nature of the goods, not the external or redistributive effect. Analogously, in COFOG-Special an energy conservation subsidy to a car-maker is considered as individual because a car is an individual good. Second, there is no reason to assume that the public funding share of a subsidised individual good has any relation to the size of the external or distributive effect. Goods may become subsidised because of rent seeking, lobbying, etc. Perhaps there is no external or redistributive effect at all ${ }^{22}$.

21 The assumption was tested for some countries and turned out to be acceptable. However, it is known that in at least some federal countries (Austria, the United States), the sub-sector of states also contributes to the financing of basic research. This means that the procedure may lead to a certain overestimation of central government expenditure on basic research in those countries and an underestimation (namely at zero) of state expenditures for this purpose.

22 An alternative way of distinguishing between subsidies for Individual and Collective goods would be to treat consumer subsidies as expenditures for individual goods and producer subsidies as expenditures for collective goods. However, from an economic point of view this way of splitting makes little sense: in competitive markets all subsidies in the mentioned COFOG groups finally end up in the pocket of the consumer. 
37. Apart from the three splits that COFOG-Special adds to regular COFOG, COFOG-Special deviates from regular COFOG in that some regular COFOG groups have been split or merged. This is the case for:

- General public services has for the transfers in cash part been split in: International co-operation, General purpose and block grants and Interest, and for the goods in kind part in General governance services and Basic research.

- Economic affairs has for the collective goods in kind part been split in Infrastructure and spatial development and Market regulation.

- A Collective goods in kind part of Housing and community amenities have been merged with a Collective goods in kind, part of Economic affairs, to form the group Infrastructure and spatial development.

- Collective goods in kind parts of Environmental protection, Economic affairs, Health, Recreation, culture and religion, Education and Social protection have been merged to form the group Market regulation.

- Individual goods in kind parts of all $1^{\text {st }}$ level COFOG groups have been merged to form the group Subsidies.

- The Individual goods in kind part of $1^{\text {st }}$ level COFOG group of Social protection have been split off to form the group Social services. The remaining individual transfers in cash part forms the group Social cash transfers.

38. For the sake of simplicity and in order to avoid using terms that have a different meaning in regular COFOG or in the economic classification, new names were introduced for the COFOG-Special groups that are generated by splits or mergers ${ }^{23}$.

39. Annex I summarizes the computation of the expenditure tables. The methods used imply that the totals of the tables are based on Eurostat data.

\section{Revenues}

40. Data on tax revenues other than social contributions, social contributions, grants and non-tax non-grant revenue are available from the OECD statistics. The table also provides information on grants computed from Eurostat expenditure data. This provides a partial specification of the current and capital transfers.

41. Social security contributions are sometimes treated as (earmarked) taxes (for instance in OECD Revenue Statistics), but in the revenue table they are presented as a separate kind of revenues in line with the SNA93.

42. Both the earmarked and non-earmarked grants are taken from the expenditure data. The earmarked grants are calculated by adding up Other current and Capital transfers of all regular COFOG groups except Transfers of a general character between different levels of government flowing to a sub-sector from all other sub-sectors (according to Eurostat table 11 for each sub-sector) ${ }^{24}$. The non-earmarked grants are calculated by adding up Other current and Capital transfer of the $2^{\text {nd }}$ level COFOG group Transfers of a general character between different levels of government flowing to a sub-sector from all other sub-sectors (according to Eurostat table 11 for each sub-sector). Note that grants from other levels of government do not occur in the general government table because of consolidation.

43. Non-tax non-grant revenues are also available from the OECD statistics. The non-tax non-grant revenues consist of: (a) Sales and fees, (b) Property income, and (c) Subsidies.

44. Annex II summarizes the computation of the revenue tables.

\footnotetext{
23 With the exception of Basic research which is also the name of the regular COFOG group Basic research.

24 If $2^{\text {nd }}$ level COFOG data are not available for sub-sectors, the estimation method explained in par. 31 will be used.
} 


\section{Employment by COFOG-Special groups}

45. The PFED derives employment by COFOG-Special groups from employment by COFOG groups in the same way as it derives expenditures by COFOG-Special groups from expenditures by COFOG groups. Employment data by COFOG groups are starting to become available from the International Labour Organisation (Laborsta database) as from 2011. Laborsta data will not only be available in persons employed but also in full time equivalents.

46. Employment can only occur in the 11 goods in kind groups that have compensation of employment as one of their expenditure components. In cases where a COFOG-Special group is formed by summation or subtraction of $2^{\text {nd }}$ level COFOG groups, employment in the $1^{\text {st }}$ level COFOG group is split over $2^{\text {nd }}$ level COFOG groups in proportion to the correspondent compensation of employees component in their funding ${ }^{25}$.

47. In cases were employment by COFOG groups is not yet available from the Laborsta database, an estimation method has been used. According to this method, employment in COFOG-Special groups is derived from employment in general government and its sub-sectors by distribution of (sub-)sector employment over COFOG-Special groups in proportion to the compensation of employees component of expenditures, while taking account of salary differences between COFOG-Special groups.

48. Salary information is available in international databases by the ISIC classification (International Standard Industrial Classification of all Economic Activities), known in Eurostat as the NACE classification (Nomenclature générale des Activités économiques dans la Communauté Européenne; Statistical classification of economic activities in the European Union). In view of the spread of annual salaries in ISIC groups (available from Eurostat labour market statistics, three salary groups have been distinguished for the distribution of (sub-)sector employment over COFOGSpecial groups:

1. COFOG-Special group Health;

2. COFOG-Special group Education;

3. All other COFOG-Special groups in kind (in COFOG-Special groups in cash there is no employment).

49. Average full time salaries for these groups will provisionally ${ }^{26}$ be taken from Eurostat data (labour market statistics) for NACE groups Q (Health), P (Education) and O (Public Administration and defence; compulsory social security $)^{27}$.

50. The estimation method assumes that the average salaries per FTE in the three groups will have the same proportional relations in all (sub-)sectors although the absolute amounts may be different per (sub-) sector.

51. The distribution procedure proceeds in two steps. First, a standardized average full time salary index for COFOG-Special groups in general government and the sub-sectors of general government is defined. The index is a measure for the average annual salary of an employee in a COFOG-Special group, relative to the average annual salary of an employee in the (sub-)sector (the index for the average salary in the (sub-)sector $=1)^{28}$.

25 For instance, as far as compensation of employees is concerned, the COFOG-Special group General governance services consists of $1^{\text {st }}$ level regular COFOG group General public services minus $2^{\text {nd }}$ level regular COFOG group Basic research. Provided that employment for General public services is available, employment for Basic research is derived as the share of employment for General public services that is proportional to the share of compensation of employees for Basic research in compensation of employees for General public services.

26 The OECD Secretariat is conducting test procedures on data from labour market statistics and other sources. A definitive decision about the source to be used will be taken later. It is also possible that salary data from national sources will be used.

27 This is possible because until now the PFED contains only EU countries.

28 Note that average salary data for FTEs are only used to derive the index. For this reason it does not matter whether the average salary data include the same components as compensation of employees data (in particular pension premiums and imputed employer's social security contributions), as long as they all do in the same way and as long as the components are roughly proportional to compensation per employee. 
52. Second, full time employment in the COFOG-Special groups in the (sub-)sectors is computed, taking account of the salary differences between COFOG-Special groups. The formula used amounts to:

Empl.

$\begin{aligned} & \text { COFOG- } \\ & \text { Special }\end{aligned}=\frac{\text { Comp. empl. COFOG-Sp. gr. }}{\text { Comp. empl. Total (sub-)sector }} \quad X \quad \frac{\text { Empl. (Sub-)sector FTEs }}{\text { Salary index COFOG-Sp. gr. }}$ group

This formula implies that if average full time salary in the COFOG-Special group is higher than average in the subsector, employment in the COFOG-Special group is lower (compared to an equal distribution).

53. Employment in the (sub-)sector in FTEs is available from the Laborsta database. If Laborsta does only provide (sub-)sector employment in persons employed (headcount) a conversion procedure is applied. For that purpose total hours worked per year in NACE group O: Public administration and defence, compulsory social security (Eurostat Labour market statistics) is divided by persons employed (headcount) in NACE group O (Eurostat labour market statistics). This yields the average hours worked per person per year in NACE group O. The conversion coefficient is now defined as average hours worked per person employed per year in NACE group O divided by hours worked per year by an FTE (as defined by national legislation ${ }^{29}$ ). This coefficient is probably somewhat lower than 1. The conversion coefficient is applied to (sub-)sector employment in persons employed (headcount) in order to obtain (sub-)sector employment in FTEs.

54. For reasons of internal consistency, full time employment in COFOG-Special groups in general government is computed as the sum of full time employment in COFOG-Special groups in the sub-sectors, if sub-sector employment data are available (see Annex III). If sub-sector employment data are not available, COFOG-Special groups can only be estimated for general government employment, which in that case is done by direct application of the formula mentioned in par. 52.

55. Annex III contains a more details of the estimation method and shows that it meets some consistency conditions.

29 Data on official full time working hours (as defined by national legislation) can be found in "Government at a Glance 2011", Table D4 (OECD, 2011). 


\section{References}

BUD (2007a), Working Paper Modified COFOG and Mode of Production classifications, OECD, Paris.

BUD (2007b), COFOG-SPECIAL, Working paper on test procedure for five European countries, OECD, Paris.

European Commission, Economy and Finance data (November 2008), http://epp.eurostat.ec.europa.eu/portal/ page?_pageid $=0,1136173,0 \_45570701 \& \_d a d=$ portal\&_schema $=$ PORTAL.

Eurostat (1996), European System of Accounts: ESA 1995, Office for Official Publications of the European Communities, Luxembourg.

Eurostat (2007), Manual on sources and methods for the compilation of COFOG statistics, Eurostat, Luxembourg.

International Labour Organization, Laborsta database of labour statistics (November 2008), http://laborsta.ilo.org/.

International Monetary Fund (2001), Government Finance Statistics Manual 2001 (GFSM 2001), International Monetary Fund, Washington DC.

International Monetary Fund (2008), Government Finance Statistics Yearbook, IMF, Washington DC.

Musgrave, R.A. (1959), The Theory of Public Finance. A Study in Public Economy, McGraw-Hill, New York.

OECD, National Account Statistics.

OECD (2005), Reallocation: The Role of Budget Institutions, OECD Publishing, Paris.

OECD (2011), Government at a Glance, OECD Publishing, Paris.

Pilichowski, E. and E. Turkisch (2008a), "Employment in Government in the Perspective of the Production Costs of Goods and Services in the Public Domain", OECD Working Papers on Public Governance, No. 8, OECD Publishing, Paris.

Pilichowski, E. and E. Turkisch (2008b), The State of the Public Service in OECD Countries, OECD Publishing, Paris.

System of National Accounts (SNA) 1993, Brussels/Luxembourg, New York, Paris, Washington DC.

UN, CEC, IMF, OECD, and the World Bank (2003), System of National Accounts 1993, United Nations, New York. 
Annex I -- Methods used to construct the COFOG-Special expenditure tables

\begin{tabular}{|c|c|c|c|c|}
\hline \multirow{2}{*}{$\begin{array}{l}\text { Collective/ } \\
\text { individual }\end{array}$} & \multirow{2}{*}{$\begin{array}{l}\text { Cash/ } \\
\text { in kind }\end{array}$} & \multirow{2}{*}{ COFOG-Special } & \multicolumn{2}{|c|}{ Source (table 1100) } \\
\hline & & & COFOG $1^{\text {st }} \& 2^{\text {nd }}$ level & Economic classification \\
\hline \multirow[t]{9}{*}{$\begin{array}{l}\text { Collective } \\
\text { goods }\end{array}$} & \multirow[t]{9}{*}{$\begin{array}{l}\text { Goods in } \\
\text { kind }\end{array}$} & \multirow[t]{7}{*}{$\begin{array}{l}\text { General governance } \\
\text { services }\end{array}$} & $\begin{array}{l}\text { Executive and legislative organs, } \\
\text { financial and fiscal affairs, external } \\
\text { affairs (011) }\end{array}$ & $\begin{array}{l}\text { Compensation of employees } \\
\text { Intermediate consumption etc. } \\
\text { Gross capital formation etc. } \\
\text { Property income } \\
\text { Social benefits }\end{array}$ \\
\hline & & & Foreign economic aid (012) & $\begin{array}{l}\text { Compensation of employees } \\
\text { Intermediate consumption etc. } \\
\text { Gross capital formation etc. } \\
\text { Property income } \\
\text { Social benefits }\end{array}$ \\
\hline & & & General services (013) & $\begin{array}{l}\text { Compensation of employees } \\
\text { Intermediate consumption etc. } \\
\text { Gross capital formation etc. } \\
\text { Property income } \\
\text { Other current transfers } \\
\text { Capital transfers } \\
\text { Social benefits }\end{array}$ \\
\hline & & & $\begin{array}{l}\text { Research and Development } \\
\text { General public services }(015)\end{array}$ & $\begin{array}{l}\text { Compensation of employees } \\
\text { Intermediate consumption etc, } \\
\text { Gross capital formation etc. } \\
\text { Property income } \\
\text { Other current transfers } \\
\text { Capital transfers } \\
\text { Social benefits } \\
\end{array}$ \\
\hline & & & $\begin{array}{l}\text { General public service not } \\
\text { elsewhere classified (016) }\end{array}$ & $\begin{array}{l}\text { Compensation of employees } \\
\text { Intermediate consumption etc, } \\
\text { Gross capital formation etc. } \\
\text { Property income } \\
\text { Other current transfers } \\
\text { Capital transfers } \\
\text { Social benefits }\end{array}$ \\
\hline & & & Public debt transactions (017) & $\begin{array}{l}\text { Compensation of employees } \\
\text { Intermediate consumption etc. } \\
\text { Gross capital formation etc. } \\
\text { Other current transfers } \\
\text { Capital transfers } \\
\text { Social benefits } \\
\end{array}$ \\
\hline & & & $\begin{array}{l}\text { Transfers of a general character } \\
\text { between different levels of } \\
\text { government }(018)\end{array}$ & $\begin{array}{l}\text { Compensation of employees } \\
\text { Intermediate consumption etc. } \\
\text { Gross capital formation etc. } \\
\text { Property income } \\
\text { Social benefits }\end{array}$ \\
\hline & & Basic research & Basic research $(014)^{*}$ & $\begin{array}{l}\text { Compensation of employees } \\
\text { Intermediate consumption etc. } \\
\text { Gross capital formation etc. } \\
\text { Property income } \\
\text { Other current transfers } \\
\text { Capital transfers } \\
\text { Social benefits } \\
\end{array}$ \\
\hline & & Defence & Defence (02) & $\begin{array}{l}\text { Compensation of employees } \\
\text { Intermediate consumption etc. } \\
\text { Gross capital formation etc. } \\
\text { Property income } \\
\text { Other current transfers } \\
\text { Capital transfers } \\
\text { Social benefits } \\
\end{array}$ \\
\hline
\end{tabular}




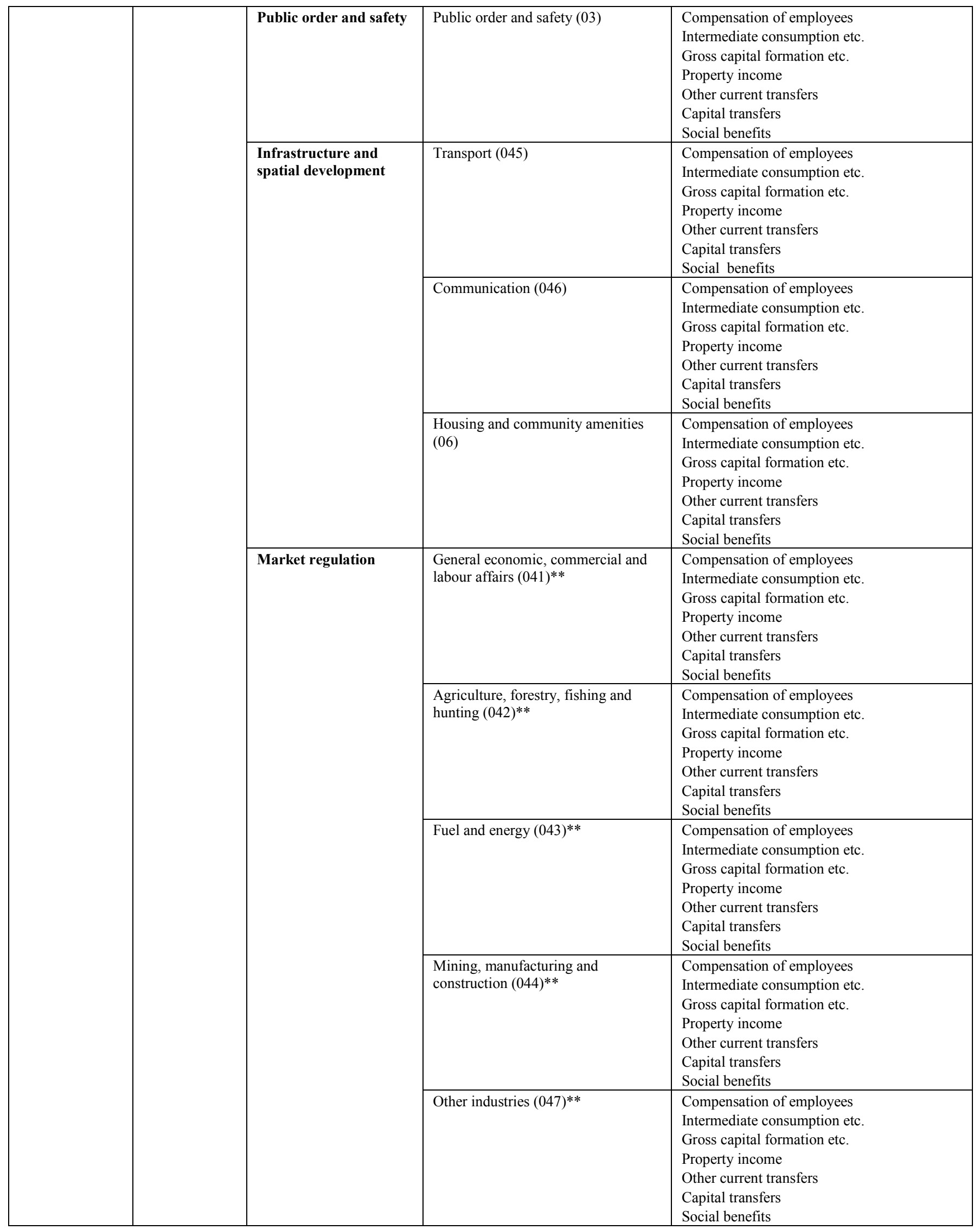




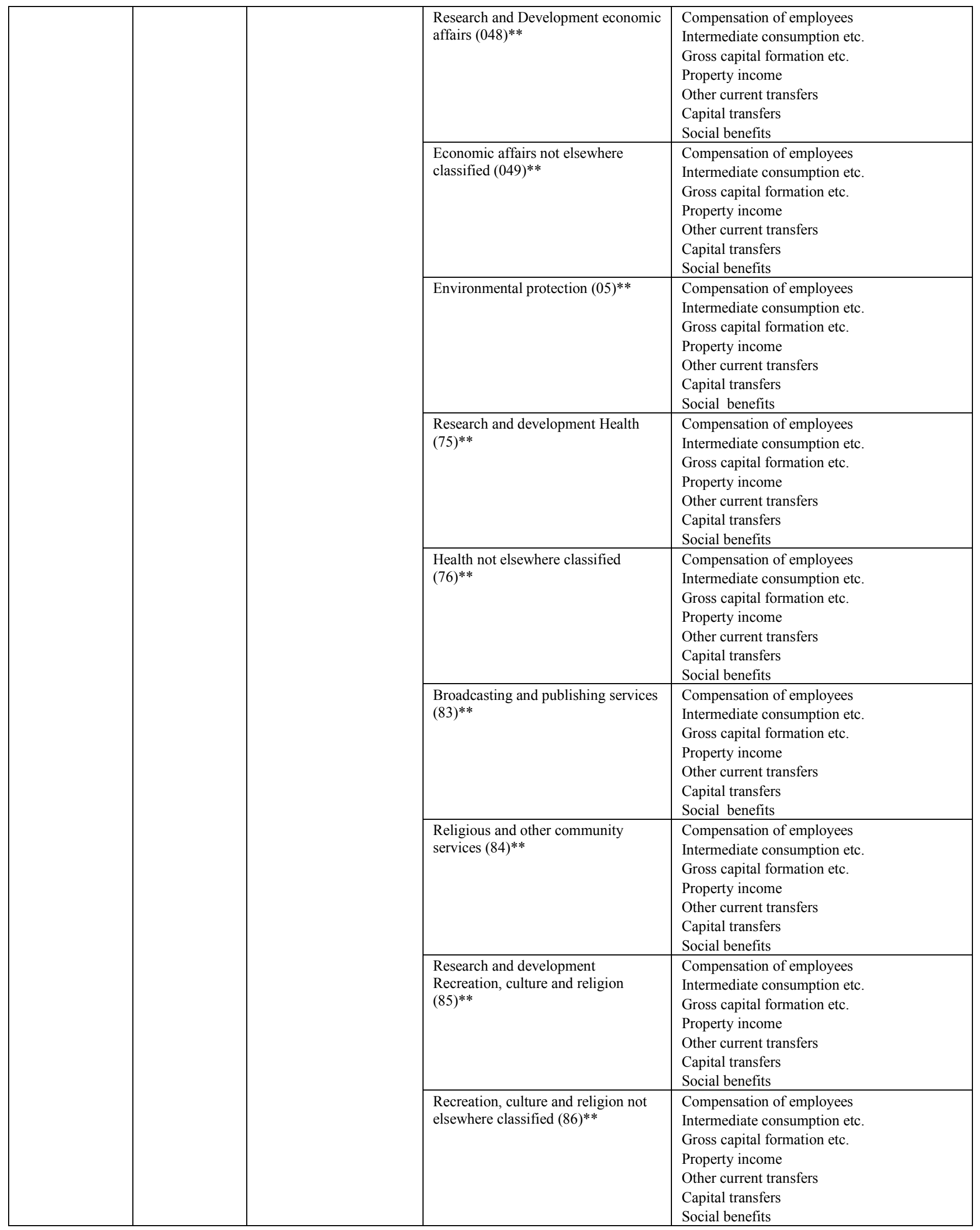




\begin{tabular}{|c|c|c|c|c|}
\hline & & & $\begin{array}{l}\text { Research and development Education } \\
(097)^{* *}\end{array}$ & $\begin{array}{l}\text { Compensation of employees } \\
\text { Intermediate consumption etc. } \\
\text { Gross capital formation etc. } \\
\text { Property income } \\
\text { Other current transfers } \\
\text { Capital transfers } \\
\text { Social benefits } \\
\end{array}$ \\
\hline & & & $\begin{array}{l}\text { Education not elsewhere classified } \\
(98)^{* *}\end{array}$ & $\begin{array}{l}\text { Compensation of employees } \\
\text { Intermediate consumption etc. } \\
\text { Gross capital formation etc. } \\
\text { Property income } \\
\text { Other current transfers } \\
\text { Capital transfers } \\
\text { Social benefits } \\
\end{array}$ \\
\hline & & & $\begin{array}{l}\text { Research and development Social } \\
\text { protection }(108)^{* *}\end{array}$ & $\begin{array}{l}\text { Compensation of employees } \\
\text { Intermediate consumption etc. } \\
\text { Gross capital formation etc. } \\
\text { Property income } \\
\text { Other current transfers } \\
\text { Capital transfers }\end{array}$ \\
\hline & & & $\begin{array}{l}\text { Social protection not elsewhere } \\
\text { classified }(109)^{* *}\end{array}$ & $\begin{array}{l}\text { Compensation of employees } \\
\text { Intermediate consumption etc. } \\
\text { Gross capital formation etc. } \\
\text { Property income } \\
\text { Other current transfers } \\
\text { Capital transfers }\end{array}$ \\
\hline & $\begin{array}{l}\text { Transfers } \\
\text { in cash }\end{array}$ & $\begin{array}{l}\text { International co- } \\
\text { operation }\end{array}$ & $\begin{array}{l}\text { Executive and legislative organs, } \\
\text { financial and fiscal affairs, external } \\
\text { affairs }(011)^{*}\end{array}$ & $\begin{array}{l}\text { Other current transfers } \\
\text { Capital transfers }\end{array}$ \\
\hline & & . & Foreign economic aid $(012)^{*}$ & $\begin{array}{l}\text { Other current transfers } \\
\text { Capital transfers }\end{array}$ \\
\hline & & $\begin{array}{l}\text { General purpose and } \\
\text { block grants }\end{array}$ & $\begin{array}{l}\text { Transfers of a general character } \\
\text { between different levels of } \\
\text { government }(018)^{* * *}\end{array}$ & $\begin{array}{l}\text { Other current transfers } \\
\text { Capital transfers }\end{array}$ \\
\hline & & Interest & Public debt transactions $(017)^{* * * *}$ & Property income \\
\hline $\begin{array}{l}\text { Individual } \\
\text { goods }\end{array}$ & $\begin{array}{l}\text { Goods in } \\
\text { kind }\end{array}$ & Health & $\begin{array}{l}\text { Medical products, appliances and } \\
\text { equipment (71) }\end{array}$ & $\begin{array}{l}\text { Compensation of employees } \\
\text { Intermediate consumption etc. } \\
\text { Gross capital formation etc. } \\
\text { Property income } \\
\text { Other current transfers } \\
\text { Capital transfers } \\
\text { Social benefits }\end{array}$ \\
\hline & & & Outpatient services (72) & $\begin{array}{l}\text { Compensation of employees } \\
\text { Intermediate consumption etc. } \\
\text { Gross capital formation etc. } \\
\text { Property income } \\
\text { Other current transfers } \\
\text { Capital transfers } \\
\text { Social benefits } \\
\end{array}$ \\
\hline & & & Hospital services (73) & $\begin{array}{l}\text { Compensation of employees } \\
\text { Intermediate consumption etc. } \\
\text { Gross capital formation etc. } \\
\text { Property income } \\
\text { Other current transfers } \\
\text { Capital transfers } \\
\text { Social benefits } \\
\end{array}$ \\
\hline & & & Public health services (74) & $\begin{array}{l}\text { Compensation of employees } \\
\text { Intermediate consumption etc. } \\
\text { Gross capital formation etc. } \\
\text { Property income } \\
\text { Other current transfers } \\
\text { Capital transfers } \\
\text { Social benefits } \\
\end{array}$ \\
\hline
\end{tabular}




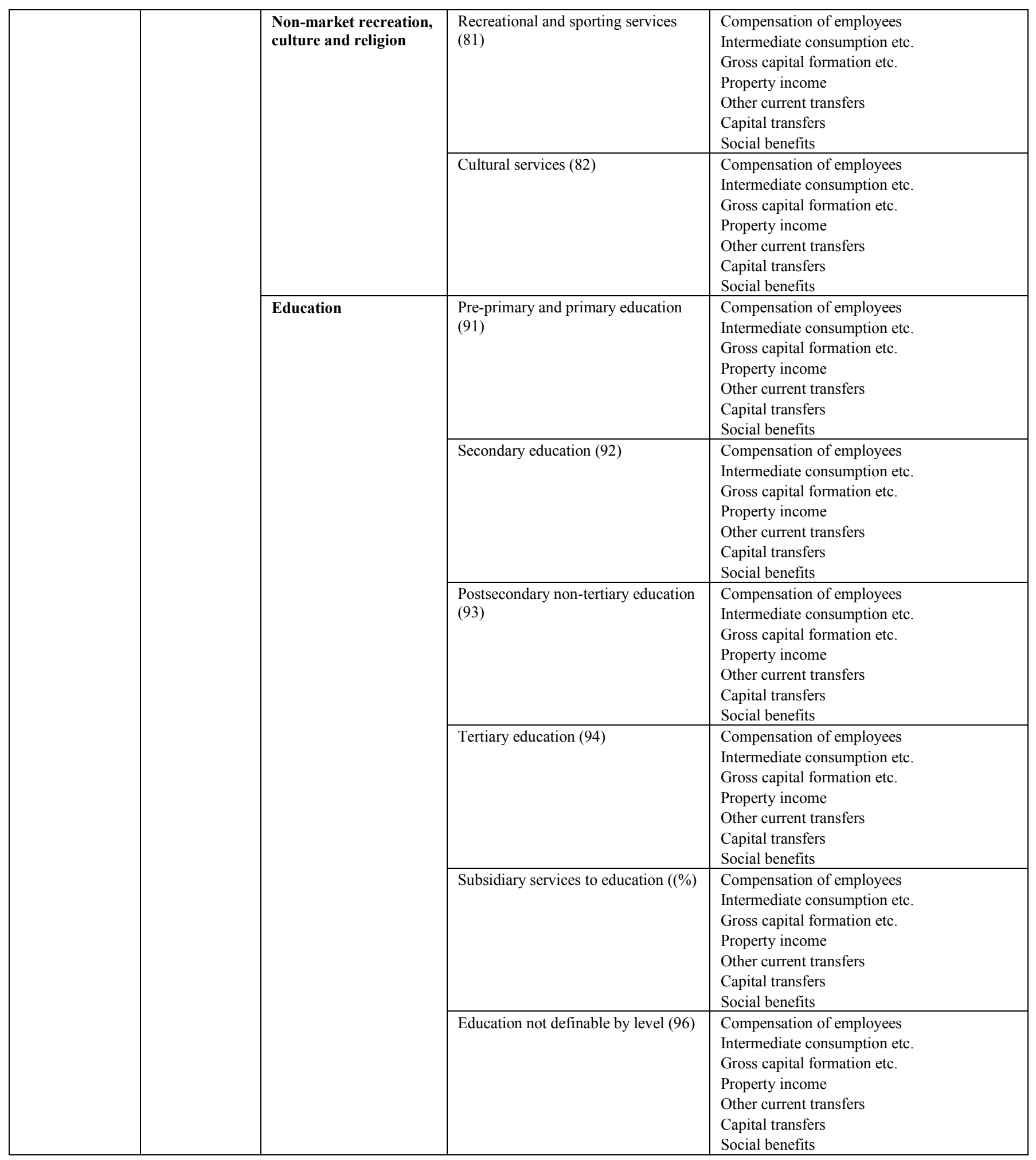




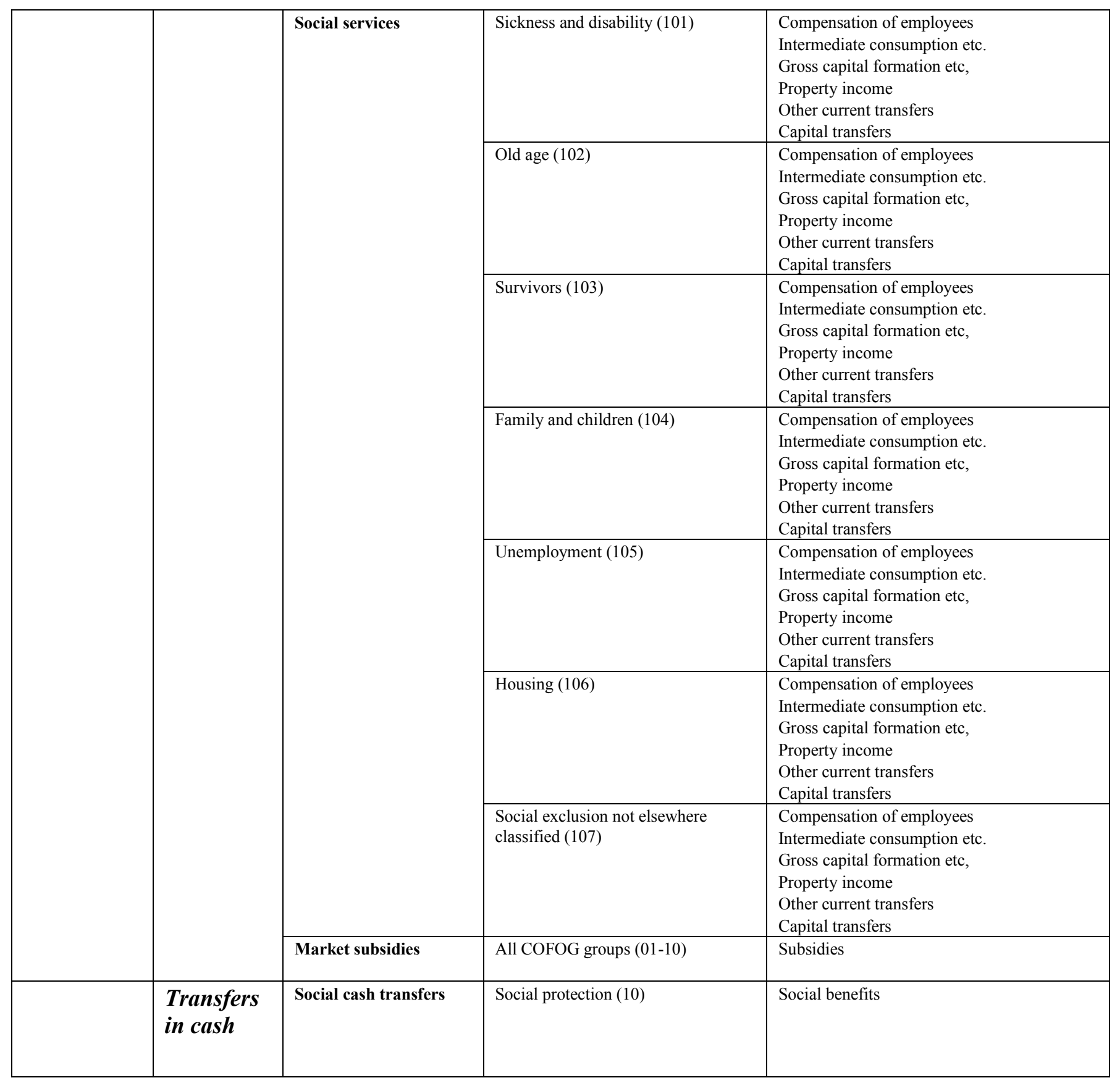

* If $2^{\text {nd }}$ level COFOG data are lacking for sub-sectors, the general government figure is attributed to central government. See par. 31 and 34.

** If $2^{\text {nd }}$ level COFOG data are lacking for sub-sectors it is assumed that the proportion of Market regulation in $1^{\text {st }}$ level COFOG groups (a) Economic affairs, (b) Recreation, culture and religion, (c) Health, (d) Education and (e) Social protection is identical in all sub-sectors to the proportion of Market regulation in these $1^{\text {st }}$ level COFOG groups in General government. See par. 34.

*** If $2^{\text {nd }}$ level COFOG data are lacking for sub-sectors, it is assumed that apart from the (imputed) other current transfers and capital transfers in $2^{\text {nd }}$ level COFOG groups Basic research, Executive and legislative organs, financial and fiscal affairs, external affairs and Foreign economic aid, there exist no other current transfers and no capital transfers in $1^{\text {st }}$ level COFOG group General public services than those in $2^{\text {nd }}$ level COFOG group Transfers of $a$ general character between different levels of government. See par. 31.

**** If $2^{\text {nd }}$ level COFOG data are lacking for sub-sectors, it is assumed that apart from the (imputed) Property income in $2^{\text {nd }}$ level COFOG group Basic Research $^{30}$ there exist no other Property income expenditures in the $1^{\text {st }}$ level COFOG group General public services than those in $2^{\text {nd }}$ level COFOG group Public debt transactions. See par. 34. 
Annex II -- Methods used to construct the revenue tables

\begin{tabular}{|c|c|c|}
\hline $\begin{array}{l}\text { Government at a Glance } \\
\text { Public Budgeting and Employment }\end{array}$ & OECD GOVACS & $\begin{array}{l}\text { GOVACS } \\
\text { Code }\end{array}$ \\
\hline \multicolumn{3}{|l|}{ Taxes } \\
\hline Indirect taxes & Taxes on production and imports, receivable & GD2R \\
\hline Direct taxes & Current taxes on income and wealth, receivable & GD5R \\
\hline Capital taxes & Capital taxes & GD91R \\
\hline \multicolumn{3}{|l|}{ Social contributions } \\
\hline Social contributions & Social contributions & GD61R \\
\hline \multicolumn{3}{|l|}{ Transfers } \\
\hline \multirow[t]{3}{*}{ Current and capital transfers } & Current and capital transfers, receivable & $\begin{array}{l}\text { GD7R } \\
\text { GD92R_D99R }\end{array}$ \\
\hline & $\begin{array}{l}\text { Of which earmarked grants from other } \\
\text { units of government (Eurostat) }\end{array}$ & - \\
\hline & $\begin{array}{l}\text { Of which non-earmarked grants from other units } \\
\text { of government (Eurostat) }\end{array}$ & - \\
\hline \multicolumn{3}{|l|}{ Non-tax non-grant revenues } \\
\hline \multirow[t]{2}{*}{ Sales and fees } & Market output and output for own final use & GP11_P12R \\
\hline & Payments for non-market output & GP131R \\
\hline Property income & Property income, receivable & GD4R \\
\hline Subsidies & Other subsidies on production, receivable & D39R \\
\hline Total revenues & Total revenues & GTRGS13 \\
\hline
\end{tabular}




\section{Annex III -- Distribution of (sub-)sector employment over COFOG-Special groups}

1. This annex explains the distribution procedure in the same two steps as the main text of this note.

2. First, a standardized average full time salary index for COFOG-Special groups in the sub-sectors of general government is defined. The indexes are defined relative to average salary for full time employment in the sub-sectors, as follows:

$\mathrm{Ac}=\mathrm{Cc} / \mathrm{Ec}$

$\mathrm{Sc} 1=\mathrm{Ac} 1 / \mathrm{Ac}$

$\mathrm{Sc} 2=\mathrm{Ac} 2 / \mathrm{Ac}$

$\mathrm{Sc} 3=\mathrm{Ac} 3 / \mathrm{Ac}$

$\mathrm{Al}=\mathrm{Cl} / \mathrm{El}$

$\mathrm{S} 11=\mathrm{A} 11 / \mathrm{Al}$

$\mathrm{S} 12=\mathrm{Al} 2 / \mathrm{Al}$

$\mathrm{S} 13=\mathrm{A} 13 / \mathrm{Al}$

Idem for other sub-sectors if they exist.

Given that Ac1 : Ac2 : Ac3 = Âg1 : Âg2 : Âg3 (or Ac1/Ac2 = Âg1/Âg2 and Ac1/Ac3 = Âg1/Âg3), it follows that:

$\mathrm{Sc} 1=(\hat{\mathrm{A} g} 1 / \mathrm{Cc}) *(\mathrm{Cc} 1 / \hat{\mathrm{A} g} 1+\mathrm{Cc} 2 / \hat{\mathrm{A} g} 2+\mathrm{Cc} 3 / \hat{\mathrm{A} g} 3)$

$\mathrm{Sc} 2=(\hat{\mathrm{A} g} 2 / \mathrm{Cc}) *(\mathrm{Cc} 1 / \hat{\mathrm{A} g} 1+\mathrm{Cc} 2 / \hat{\mathrm{A} g} 2+\mathrm{Cc} 3 / \hat{\mathrm{A} g} 3)$

$\mathrm{Sc} 3=(\hat{\mathrm{A} g} 3 / \mathrm{Cc}) *(\mathrm{Cc} 1 / \hat{\mathrm{A} g} 1+\mathrm{Cc} 2 / \hat{\mathrm{A} g} 2+\mathrm{Cc} 3 / \hat{\mathrm{A} g} 3)$

Furthermore, given that Al1 : A12 : Al3 = Âg1 : Âg2 : Âg3 (or Al1/A12 = Âg1/Âg2 and Al1/Al3 = $\hat{A} g 1 / \hat{A} g 3)$, it follows that:

$\mathrm{S} 11=(\hat{\mathrm{A} g} 1 / \mathrm{Cl}) *(\mathrm{Cl} 1 / \hat{\mathrm{A} g} 1+\mathrm{Cl} 2 / \hat{\mathrm{A} g} 2+\mathrm{Cl} 3 / \hat{\mathrm{A} g} 3)$

$\mathrm{S} 12=(\hat{\mathrm{Ag}} 2 / \mathrm{Cl}) *(\mathrm{Cl} 1 / \hat{\mathrm{A} g} 1+\mathrm{Cl} 2 / \hat{\mathrm{A} g} 2+\mathrm{Cl} 3 / \hat{\mathrm{Ag}} 3)$

$\mathrm{Sl} 3=(\hat{\mathrm{Ag}} 3 / \mathrm{Cl}) *(\mathrm{Cl} 1 / \hat{\mathrm{A} g} 1+\mathrm{Cl} 2 / \hat{\mathrm{Ag}} 2+\mathrm{Cl} 3 / \hat{\mathrm{A} g} 3)$

with:

$\hat{A} g 1=$ average salary per FTE in COFOG-Special group Health in general government $\hat{\mathrm{A} g} 2=$ average salary per FTE in COFOG-Special group Education in general government $\hat{\mathrm{A} g} 3$ = average salary per FTE in all other COFOG-Special groups in general government

Ac1 = average salary per FTE in COFOG-Special group Health in central government Ac2 = average salary per FTE in COFOG-Special group Education in central government Ac3 = average salary per FTE in all other COFOG-Special groups in central government Ac $=$ average salary per FTE in central government 
$\mathrm{Cc} 1=$ compensation of employment in COFOG-Special group Health in central government

$\mathrm{Cc} 2=$ compensation of employment in COFOG-Special group Education in central government

$\mathrm{Cc} 3=$ compensation of employment in all other COFOG-Special groups in central government

$\mathrm{Cc}=$ compensation of employment in central government

Al1 = average salary per FTE in COFOG-Special group Health in local government

$\mathrm{Al} 2=$ average salary per FTE in COFOG-Special group Education in local government

$\mathrm{A} 13$ = average salary per FTE in all other COFOG-Special groups in local government

$\mathrm{Al}=$ average salary per FTE in local government

$\mathrm{Cl} 1$ = compensation of employment in COFOG-Special group Health in local government

$\mathrm{Cl} 2=$ compensation of employment in COFOG-Special group Education in local government

$\mathrm{Cl} 3=$ compensation of employment in all other COFOG-Special groups in local government

$\mathrm{Cl}=$ compensation of employment in local government

Sc1 = standardized average salary index for COFOG-Special group Health in central government

$\mathrm{Sc} 2=$ standardized average salary index for COFOG-Special group Education in central government

$\mathrm{Sc} 3=$ standardized average salary index for all other COFOG-Special groups in central government

S11 = standardized average salary index for COFOG-Special group Health in local government

S12 = standardized average salary index for COFOG-Special group Education in local government

S13 = standardized average salary index for all other COFOG-Special groups in local government

3. Second, employment in FTEs for COFOG-Special groups in the subsectors is computed, taking account of average salaries per FTE in these COFOG-Special groups, as follows:

$\mathrm{Ec} 1=(\mathrm{Cc} 1 * \mathrm{Eg}) /(\mathrm{Cc} * \mathrm{Sc} 1)$

$\mathrm{Ec} 2=(\mathrm{Cc} 2 * \mathrm{Eg}) /(\mathrm{Cc} * \mathrm{Sc} 2)$

$\mathrm{Ec} 3=(\mathrm{Cc} 3 * \mathrm{Eg}) /(\mathrm{Cc} * \mathrm{Sc} 3)$

$\mathrm{El} 1=(\mathrm{Cl1} * \mathrm{Eg}) /(\mathrm{Cl} * \mathrm{Sl} 1)$

$\mathrm{El} 2=(\mathrm{Cl} 2 * \mathrm{Eg}) /(\mathrm{Cl} * \mathrm{Sl} 2)$

$\mathrm{El} 3=(\mathrm{Cl} 3 * \mathrm{Eg}) /(\mathrm{Cl} * \mathrm{Sl} 3)$

Idem for other subsectors if they exist.

General government eemployments in COFOG-Special groups is computed as sum of full time employment in COFOG-Special groups in the sub-sectors:

$\mathrm{Eg} 1=\mathrm{Ec} 1+\mathrm{E} 11$

$\mathrm{Eg} 2=\mathrm{Ec} 2+\mathrm{El} 2$

$\mathrm{Eg} 3=\mathrm{Ec} 3+\mathrm{E} 13$ 
However, if total employment in sub-sectors is not available, employment in COFOG-Special groups in sub-sectors cannot be computed and COFOG-Special groups in general government has to be estimated directly by:

$\mathrm{Eg} 1=(\mathrm{Cg} 1 * \mathrm{Eg}) /(\mathrm{Cg} * \mathrm{Sg} 1)$

$\mathrm{Eg} 2=(\mathrm{Cg} 2 * \mathrm{Eg}) /(\mathrm{Cg} * \mathrm{Sg} 2)$

$\mathrm{Eg} 3=(\mathrm{Cg} 3 * \mathrm{Eg}) /(\mathrm{Cg} * \mathrm{Sg} 3)$

with:

Eg1 = employment in FTEs in COFOG-Special group Health in general government Eg2 = employment in FTEs COFOG-Special group Education in general government Eg3 = employment in FTEs in all other COFOG-Special groups in general government $\mathrm{Eg}=$ employment in FTEs in general government

Ec1 = employment in FTEs in COFOG-Special group Health in central government $\mathrm{Ec} 2=$ employment in FTEs in COFOG-Special group Education in central government Ec3 = employment in FTEs in all other COFOG-Special groups in central government $\mathrm{Ec}=$ employment in FTEs in central government

El1 = full time employment in COFOG-Special group Health in local government El2 = full time employment in COFOG-Special group Education in local government $\mathrm{El} 3$ = full time employment in all other COFOG-Special groups in local government $\mathrm{El}=$ employment in FTEs in local government

$\mathrm{Cg} 1=$ compensation of employment in COFOG-Special group Health in general government $\mathrm{Cg} 2=$ compensation of employment in COFOG-Special group Education in general government $\mathrm{Cg} 3=$ compensation of employment in all other COFOG-Special groups in general government $\mathrm{Cg}=$ compensation of employment in general government

$\mathrm{Sg} 1$ = standardized average salary index for COFOG-Special group Health in general government $\mathrm{Sg} 2=$ standardized average salary index for COFOG-Special group Education in general government $\mathrm{Sg} 3$ = standardized average salary index for all other COFOG-Special groups in general government

4. Note that the consistency conditions on total employment in the sub-sectors are met:

$$
\begin{aligned}
\mathrm{Ec} 1+\mathrm{Ec} 2+\mathrm{Ec} 3 & =\{(\mathrm{Cc} 1 * \mathrm{Ec}) /(\mathrm{Cc} * \mathrm{Sc} 1)\}+\{(\mathrm{Cc} 2 * \mathrm{Ec}) /(\mathrm{Cc} * \mathrm{Sc} 2)\}+\{(\mathrm{Cc} 3 * \mathrm{Ec}) /(\mathrm{Cc} * \mathrm{Sc} 3)\} \\
& =(\mathrm{Ec} / \mathrm{Cc}) *(\mathrm{Cc} 1 / \mathrm{Sc} 1+\mathrm{Cc} 2 / \mathrm{Sc} 2+\mathrm{Cc} 3 / \mathrm{Sc} 3) \\
& =\{\mathrm{Ec} /(\mathrm{Cc} 1 / \hat{\mathrm{A}} 1+\mathrm{Cc} 2 / \hat{\mathrm{A}} 2+\mathrm{Cc} 3 / \hat{\mathrm{Ag}} 3)\} *(\mathrm{Cc} 1 / \hat{\mathrm{A} g} 1+\mathrm{Cc} 2 / \hat{\mathrm{A}} \mathrm{g} 2+\mathrm{Cc} 3 / \hat{\mathrm{A}} 3) \\
& =\mathrm{Ec}
\end{aligned}
$$

and:

$$
\begin{aligned}
\mathrm{El} 1+\mathrm{El} 2+\mathrm{El} 3 & =(\mathrm{Cl} 1 * \mathrm{El}) /(\mathrm{Cl} * \mathrm{Sl} 1)+(\mathrm{Cl} 2 * \mathrm{El}) /(\mathrm{Cl} * \mathrm{Sl} 2)+(\mathrm{Cl} 3 * \mathrm{El}) /(\mathrm{Cl} * \mathrm{Sl} 3) \\
& =(\mathrm{El} / \mathrm{Cl}) *(\mathrm{Cl} 1 / \mathrm{Sl} 1+\mathrm{Cl} 2 / \mathrm{Sl} 2+\mathrm{Cl} 3 / \mathrm{Sl} 3) \\
& =\{\mathrm{El} /(\mathrm{Cl} 1 / \hat{\mathrm{Ag}} 1+\mathrm{Cl} 2 / \hat{\mathrm{A} g} 2+\mathrm{Cl} 3 / \hat{\mathrm{Ag}} 3)\} *(\mathrm{Cl} 1 / \hat{\mathrm{A} g} 1+\mathrm{Cl} 2 / \hat{\mathrm{Ag}} 2+\mathrm{Cl} 3 / \hat{\mathrm{A}} 3) \\
& =\mathrm{El}
\end{aligned}
$$


5. Note also that the consistency condition on the source data $\mathrm{Ec}+\mathrm{El}=\mathrm{Eg}$ assures that the consistency condition on total general government employment is met:

$$
\begin{aligned}
\mathrm{Eg} 1+\mathrm{Eg} 2+\mathrm{Eg} 3 & =(\mathrm{Ec} 1+\mathrm{El} 1)+(\mathrm{Ec} 2+\mathrm{El} 2)+(\mathrm{Ec} 3+\mathrm{El} 3) \\
& =(\mathrm{Ec} 1+\mathrm{Ec} 2+\mathrm{Ec} 3)+(\mathrm{El} 1+\mathrm{El} 2+\mathrm{El} 3) \\
& =\mathrm{Ec}+\mathrm{El} \\
& =\mathrm{Eg}
\end{aligned}
$$

6. Table 1 summarizes the computations. The data provided with an asterix between parentheses $(*)$ are available from the data sources (OECD national accounts, and ILO Laborsta). In the formulas the * stands for multiplication. 
Table 1 -- Distribution of employment in general government and subsectors over COFOG-Special groups if sub-sector employment totals are available

\begin{tabular}{|c|c|c|c|}
\hline & $\begin{array}{c}\text { Compensation } \\
\text { of } \\
\text { employment }\end{array}$ & $\begin{array}{l}\text { Standardized } \\
\text { average full-time salary } \\
\text { index }\end{array}$ & Employment \\
\hline $\begin{array}{l}\text { General } \\
\text { government }\end{array}$ & $\mathrm{Cg}\left({ }^{*}\right)$ & & $\operatorname{Eg}(*)$ \\
\hline $\begin{array}{l}\text { COFOG- } \\
\text { Special group } \\
\text { Health }\end{array}$ & $\operatorname{Cg} 1(*)$ & & $\mathrm{Eg} 1=\mathrm{Ec} 1+\mathrm{E} 11$ \\
\hline $\begin{array}{l}\text { COFOG- } \\
\text { Special group } \\
\text { Education }\end{array}$ & $\operatorname{Cg} 2(*)$ & & $\mathrm{Eg} 2=\mathrm{Ec} 2+\mathrm{E} 12$ \\
\hline $\begin{array}{l}\text { All other } \\
\text { COFOG- } \\
\text { Special groups }\end{array}$ & $\operatorname{Cg} 3(*)$ & & $\mathrm{Eg} 3=\mathrm{Ec} 3+\mathrm{El} 3$ \\
\hline $\begin{array}{l}\text { Central } \\
\text { government }\end{array}$ & $\mathrm{Cc}$ & 1 & $\mathrm{Ec}(*)$ \\
\hline $\begin{array}{l}\text { COFOG- } \\
\text { Special group } \\
\text { Health }\end{array}$ & $\operatorname{Cc} 1(*)$ & $\begin{array}{l}\text { Sc1 }=(\hat{A} g 1 / C c) *(C c 1 / \hat{A} g 1+C c 2 / \hat{A} g 2+ \\
\text { Cc3/Âg3) }\end{array}$ & $\mathrm{Ec} 1=(\mathrm{Cc} 1 * \mathrm{Ec}) /(\mathrm{Cc} * \mathrm{Sc} 1)$ \\
\hline $\begin{array}{l}\text { COFOG- } \\
\text { Special group } \\
\text { Education }\end{array}$ & $\operatorname{Cc} 2(*)$ & $\begin{array}{l}\mathrm{Sc} 2=(\hat{A} g 2 / \mathrm{Cc}) *(\mathrm{Cc} 1 / \hat{\mathrm{A} g} 1+\mathrm{Cc} 2 / \hat{\mathrm{A} g} 2+ \\
\mathrm{Cc} 3 / \hat{\mathrm{A} g} 3)\end{array}$ & $\mathrm{Ec} 2=(\mathrm{Cc} 2 * \mathrm{Ec}) /(\mathrm{Cc} * \mathrm{Sc} 2)$ \\
\hline $\begin{array}{l}\text { All other } \\
\text { COFOG- } \\
\text { Special groups }\end{array}$ & $\operatorname{Cc} 3(*)$ & $\begin{array}{l}\mathrm{Sc} 3=(\hat{A} g 3 / \mathrm{C}) *(\mathrm{Cc} 1 / \hat{\mathrm{A} g} 1+\mathrm{Cc} 2 / \hat{\mathrm{A} g} 2+ \\
\mathrm{Cc} 3 / \hat{\mathrm{A} g} 3)\end{array}$ & $\mathrm{Ec} 3=(\mathrm{Cc} 3 * \mathrm{Ec}) /(\mathrm{Cc} * \mathrm{Sc} 3)$ \\
\hline $\begin{array}{c}\text { Local } \\
\text { government }\end{array}$ & $\mathrm{Cl}(*)$ & 1 & El $(*)$ \\
\hline $\begin{array}{l}\text { COFOG- } \\
\text { Special group } \\
\text { Health }\end{array}$ & $\mathrm{Cl} 1\left(^{*}\right)$ & $\begin{array}{l}\mathrm{Sl} 1=(\hat{\mathrm{A} g} 1 / \mathrm{Cl}) *(\mathrm{Cl} 1 / \hat{\mathrm{A} g} 1+\mathrm{Cl} 2 / \hat{\mathrm{A} g} 2+ \\
\mathrm{Cl} 3 / \mathrm{A} \mathrm{g} 3)\end{array}$ & $\mathrm{El} 1=(\mathrm{Cl} 1 * \mathrm{El}) /(\mathrm{Cl} * 11)$ \\
\hline $\begin{array}{l}\text { COFOG- } \\
\text { Special group } \\
\text { Education }\end{array}$ & $\mathrm{Cl} 2\left(^{*}\right)$ & $\begin{array}{l}\mathrm{SI} 2=(\hat{\mathrm{A} g} 2 / \mathrm{Cl}) *(\mathrm{Cl} 1 / \hat{\mathrm{A} g} 1+\mathrm{Cl} 2 / \hat{\mathrm{A} g} 2+ \\
\mathrm{Cl} 3 / \mathrm{A} \mathrm{g} 3)\end{array}$ & $\mathrm{El} 2=(\mathrm{Cl} 2 * \mathrm{El}) /(\mathrm{Cl} * \mathrm{Sl} 2)$ \\
\hline $\begin{array}{l}\text { All other } \\
\text { COFOG- } \\
\text { Special groups }\end{array}$ & $\mathrm{Cl} 3\left(^{*}\right)$ & $\begin{array}{l}\mathrm{SI} 3=(\hat{\mathrm{A} g} 3 / \mathrm{Cl}) *(\mathrm{Cl} 1 / \hat{\mathrm{A} g} 1+\mathrm{Cl} 2 / \hat{\mathrm{A} g} 2+ \\
\mathrm{Cl} 3 / \hat{\mathrm{A}} \mathrm{g} 3)\end{array}$ & $\mathrm{El} 3=(\mathrm{Cl} 3 * \mathrm{El}) /(\mathrm{Cl} * \mathrm{Sl} 3)$ \\
\hline
\end{tabular}


Table 2 - Distribution of employment in general government over COFOG-Special groups if sub-sector employment totals are not available

\begin{tabular}{|l|l|l|l|}
\hline & \multicolumn{1}{|c|}{$\begin{array}{c}\text { Compensation } \\
\text { of } \\
\text { employment }\end{array}$} & \multicolumn{1}{|c|}{$\begin{array}{c}\text { Standardized } \\
\text { average full-time salary } \\
\text { index }\end{array}$} & \multicolumn{1}{|c|}{ Employment } \\
\hline $\begin{array}{l}\text { General } \\
\text { government }\end{array}$ & $\mathrm{Cg}\left(^{*}\right)$ & 1 & $\mathrm{Eg}(*)$ \\
\hline $\begin{array}{l}\text { COFOG- } \\
\text { Special group } \\
\text { Health }\end{array}$ & $\mathrm{Cg} 1\left(^{*}\right)$ & $\begin{array}{l}\mathrm{Sg} 1=(\hat{\mathrm{A} g} 1 / \mathrm{Cg}) *(\mathrm{Cg} 1 / \hat{\mathrm{A} g} 1+\mathrm{Cg} 2 / \hat{\mathrm{A} g} 2+ \\
\mathrm{Cg} 3 / \mathrm{Ag} 3)\end{array}$ & $\mathrm{Eg} 1=(\mathrm{Cg} 1 * \mathrm{Eg}) /(\mathrm{Cg} * \mathrm{Sg} 1)$ \\
\hline $\begin{array}{l}\text { COFOG- } \\
\text { Special group } \\
\text { Education }\end{array}$ & $\mathrm{Cg} 2\left(^{*}\right)$ & $\begin{array}{l}\mathrm{Sg} 2=(\hat{\mathrm{A} g} 2 / \mathrm{Cg}) *(\mathrm{Cg} 1 / \hat{\mathrm{A} g} 1+\mathrm{Cg} 2 / \hat{\mathrm{A} g} 2+ \\
\mathrm{Cg} 3 / \mathrm{Ag} 3)\end{array}$ & $\mathrm{Eg} 2=(\mathrm{Cg} 2 * \mathrm{Eg}) /(\mathrm{Cg} * \mathrm{Sg} 2)$ \\
\hline $\begin{array}{l}\text { All other } \\
\text { COFOG- } \\
\text { Special } \\
\text { groups }\end{array}$ & $\left.\mathrm{Cg} 3{ }^{*}\right)$ & $\begin{array}{l}\mathrm{Sg} 3=(\hat{\mathrm{A} g} 3 / \mathrm{Cg}) *(\mathrm{Cg} 1 / \hat{\mathrm{A} g} 1+\mathrm{Cg} 2 / \hat{\mathrm{A} g} 2+ \\
\mathrm{Cg} 3 / \mathrm{A} g 3)\end{array}$ & $\mathrm{Eg} 3=(\mathrm{Cg} 3 * \mathrm{Eg}) /(\mathrm{Cg} * \mathrm{Sg} 3)$ \\
\hline
\end{tabular}




\section{Annex IV -- Complete PFED tables for Estonia}

\section{Expenditures}

\begin{tabular}{|c|c|c|c|c|c|c|c|c|c|}
\hline \multicolumn{2}{|l|}{ Estonia-General government } & \multicolumn{8}{|c|}{ Expenditures $(m \ln$ EEK) } \\
\hline COFOG Special & Transaction & 2002 & 2003 & 2004 & 2005 & 2006 & 2007 & 2008 & 2009 \\
\hline \multirow[t]{9}{*}{ Total } & Compensation of employees & 798.4 & 888.9 & 985.2 & 1104.1 & 1242.2 & 1526.2 & 1830.1 & 1773.2 \\
\hline & Intermediate consumption etc. & 599.3 & 691.6 & 685.5 & 778.4 & 880.7 & 1001.5 & 1147.1 & 1070.4 \\
\hline & Subsidies & 76.1 & 75.1 & 76.8 & 83 & 114.5 & 137.5 & 161.4 & 137.4 \\
\hline & Property income, consolidated & 16.3 & 18.2 & 22 & 21.5 & 23.2 & 26.7 & 37.6 & 44.7 \\
\hline & Social benefits & 802.4 & 883.5 & 1028.4 & 1150.2 & 1333.3 & 1583.8 & 1968.7 & 2208.6 \\
\hline & Other current transfers, consolidated & 46.1 & 66.9 & 123.6 & 172.4 & 223.4 & 242 & 237.3 & 259 \\
\hline & Capital transfers, consolidated & 27.3 & 38.1 & 43.2 & 38.3 & 110.9 & 148.1 & 189.1 & 99.6 \\
\hline & Gross capital formation etc. & 416 & 373.2 & 326.6 & 408.2 & 571.3 & 777.5 & 850.5 & 667 \\
\hline & Total government expenditure & 2781.9 & 3035.5 & 3291.3 & 3756.1 & 4499.5 & 5443.3 & 6421.8 & 6259.9 \\
\hline \multirow[t]{8}{*}{ Collective goods } & Compensation of employees & 347.3 & 389.3 & 428.2 & 473.8 & 532 & 667.3 & 790.9 & 724.7 \\
\hline & Intermediate consumption etc. & 347.5 & 400.7 & 364.7 & 427.8 & 480.5 & 545.4 & 619.2 & 579.7 \\
\hline & Property income, consolidated & 16.3 & 18.2 & 22 & 21.5 & 23.2 & 26.7 & 37.6 & 44.7 \\
\hline & Social benefits & 0 & 0 & 1.9 & 2.8 & 3.4 & 7 & 7.9 & 9.6 \\
\hline & Other current transfers, consolidated & 20.3 & 37.8 & 91.9 & 132.4 & 179.4 & 182.1 & 177.1 & 189.3 \\
\hline & Capital transfers, consolidated & 25.7 & 33.7 & 26.9 & 33 & 102.3 & 138 & 172.2 & 88.3 \\
\hline & Gross capital formation etc. & 250.6 & 211.7 & 170.7 & 207.1 & 272.7 & 444.8 & 445.6 & 421.3 \\
\hline & Total government expenditure & 1007.7 & 1091.4 & 1106.3 & 1298.4 & 1593.5 & 2011.3 & 2250.5 & 2057.6 \\
\hline \multirow[t]{8}{*}{ Collective goods in kind } & Compensation of employees & 347.3 & 389.3 & 428.2 & 473.8 & 532 & 667.3 & 790.9 & 724.7 \\
\hline & Intermediate consumption etc. & 347.5 & 400.7 & 364.7 & 427.8 & 480.5 & 545.4 & 619.2 & 579.7 \\
\hline & Property income, consolidated & 0 & 0 & 0 & 0 & 0 & 0 & 0 & 0 \\
\hline & Social benefits & 0 & 0 & 1.9 & 2.8 & 3.4 & 7 & 7.9 & 9.6 \\
\hline & Other current transfers, consolidated & 16 & 29.3 & 44.4 & 49.6 & 47.6 & 56.7 & 57 & 66 \\
\hline & Capital transfers, consolidated & 11.8 & 28.3 & 25.5 & 31.3 & 101.3 & 134.4 & 167.4 & 78.8 \\
\hline & Gross capital formation etc. & 250.6 & 211.7 & 170.7 & 207.1 & 272.7 & 444.8 & 445.6 & 421.3 \\
\hline & Total government expenditure & 973.2 & 1059.3 & 1035.4 & 1192.4 & 1437.5 & 1855.6 & 2088 & 1880.1 \\
\hline \multirow[t]{8}{*}{ General governance services } & Compensation of employees & 98.3 & 106.7 & 114.9 & 125 & 140.4 & 172.9 & 201.5 & 184.5 \\
\hline & Intermediate consumption etc. & 84.6 & 87.2 & 77.8 & 77.1 & 85.1 & 90.5 & 104.7 & 95.6 \\
\hline & Property income, consolidated & 0 & 0 & 0 & 0 & 0 & 0 & 0 & 0 \\
\hline & Social benefits & 0 & 0 & 0.5 & 0.1 & 0.1 & 0.1 & 0.2 & 0.3 \\
\hline & Other current transfers, consolidated & 1.3 & 2.8 & 1.5 & 2.5 & 2.5 & 3 & 3.4 & 7.7 \\
\hline & Capital transfers, consolidated & 0 & 0 & 0 & 0 & 0.2 & 0 & 0 & 0 \\
\hline & Gross capital formation etc. & 60.6 & 42.7 & -22.7 & -12.9 & 6.2 & 27.8 & -49.2 & 8.6 \\
\hline & Total government expenditure & 244.8 & 239.4 & 172 & 191.8 & 234.5 & 294.3 & 260.6 & 296.7 \\
\hline \multirow[t]{8}{*}{ Basic research } & Compensation of employees & 9 & 10 & 10.7 & 10.8 & 13.1 & 14 & 17.7 & 17.6 \\
\hline & Intermediate consumption etc. & 4.5 & 5 & 5.3 & 5.7 & 7.1 & 6.9 & 8 & 7.5 \\
\hline & Property income, consolidated & 0 & 0 & 0 & 0 & 0 & 0 & 0 & 0 \\
\hline & Social benefits & 0 & 0 & 0.3 & 0.5 & 0.8 & 1.2 & 1.6 & 2 \\
\hline & Other current transfers, consolidated & 0.6 & 0.5 & 0 & 0.2 & 0 & 0.2 & 0 & 0.1 \\
\hline & Capital transfers, consolidated & 0 & 0 & 0 & 0 & 0 & 0 & 0 & 0.3 \\
\hline & Gross capital formation etc. & 0.2 & 0.3 & 5.6 & 3.5 & 6.4 & 10 & 15.4 & 12 \\
\hline & Total government expenditure & 14.3 & 15.8 & 21.9 & 20.7 & 27.4 & 32.3 & 42.7 & 39.5 \\
\hline Defence & Compensation of employees & 29.9 & 36.4 & 45.9 & 54.7 & 62 & 78.2 & 96 & 89.8 \\
\hline & Intermediate consumption etc. & 38.5 & 68.5 & 45.2 & 65.9 & 79.7 & 90.1 & 111.1 & 133.1 \\
\hline & Property income, consolidated & 0 & 0 & 0 & 0 & 0 & 0 & 0 & 0 \\
\hline & Social benefits & 0 & 0 & 0.8 & 0.9 & 1 & 3.3 & 3.1 & 3.1 \\
\hline & Other current transfers, consolidated & 0 & 0.2 & 0.6 & 0.6 & 0.8 & 1.6 & 0.5 & 0.4 \\
\hline & Capital transfers, consolidated & 0.3 & 0 & 0 & 0 & 0 & 0.8 & 0 & 0 \\
\hline & Gross capital formation etc. & 39.2 & 42.9 & 42.3 & 33.8 & 31.7 & 28.9 & 69.5 & 85.1 \\
\hline & Total government expenditure & 107.9 & 148 & 134.8 & 155.9 & 175.2 & 202.9 & 280.2 & 311.5 \\
\hline Public order and safety & Compensation of employees & 121.8 & 133.3 & 143.4 & 150.4 & 167.4 & 214.1 & 257.6 & 229.9 \\
\hline & Intermediate consumption etc. & 51.7 & 54.8 & 57.3 & 55.8 & 63.3 & 77 & 74.6 & 65.3 \\
\hline & Property income, consolidated & 0 & 0 & 0 & 0 & 0 & 0 & 0 & 0 \\
\hline & Social benefits & 0 & 0 & 0.1 & 0.1 & 0.1 & 0.1 & 0.1 & 0.1 \\
\hline & Other current transfers, consolidated & 0 & 0.2 & 1.7 & 1.5 & 1.4 & 2.1 & 1.5 & 1.6 \\
\hline & Capital transfers, consolidated & 0.5 & 0 & 0 & 0 & 0 & 0 & 0 & 0.1 \\
\hline & Gross capital formation etc. & 23.7 & 24.5 & 9.5 & 32.6 & 43.4 & 58 & 108 & 35.2 \\
\hline & Total government expenditure & 197.7 & 212.8 & 212 & 240.4 & 275.6 & 351.3 & 441.8 & 332.2 \\
\hline Infrastructure and spatial & Compensation of employees & 24.6 & 24 & 24.7 & 27 & 30.1 & 36 & 38.7 & 32 \\
\hline development & Intermediate consumption etc. & 67.2 & 82.1 & 73.8 & 89.5 & 100.8 & 117 & 135.5 & 117.6 \\
\hline & Property income, consolidated & 0 & 0 & 0 & 0 & 0 & 0 & 0 & 0 \\
\hline & Social benefits & 0 & 0 & 0 & 0 & 0 & 0.1 & 0.2 & 0.1 \\
\hline & Other current transfers, consolidated & 0 & 0 & 6 & 9 & 2.8 & 3.5 & 3.4 & 5.1 \\
\hline & Capital transfers, consolidated & 0 & 2.3 & 1.8 & 7.2 & 15 & 20.1 & 43.5 & 16.7 \\
\hline & Gross capital formation etc. & 88.4 & 66.8 & 114.5 & 140.4 & 187.9 & 270.5 & 263.4 & 132.4 \\
\hline & Total government expenditure & 180.2 & 175.2 & 220.8 & 273.1 & 336.6 & 447.2 & 484.7 & 303.9 \\
\hline Market regulation & Compensation of employees & 63.7 & 78.9 & 88.6 & 105.9 & 119 & 152.1 & 179.4 & 170.9 \\
\hline & Intermediate consumption etc. & 101 & 103.1 & 105.3 & 133.8 & 144.5 & 163.9 & 185.3 & 160.6 \\
\hline & Property income, consolidated & 0 & 0 & 0 & 0 & 0 & 0 & 0 & 0 \\
\hline & Social benefits & 0 & 0 & 0.2 & 1.2 & 1.4 & 2.2 & 2.7 & 4 \\
\hline & Other current transfers, consolidated & 14.1 & 25.6 & 34.6 & 35.8 & 40.1 & 46.3 & 48.2 & 51.1 \\
\hline & Capital transfers, consolidated & 11 & 26 & 23.7 & 24.1 & 86.1 & 113.5 & 123.9 & 61.7 \\
\hline & Gross capital formation etc. & 38.5 & 34.5 & 21.5 & 9.7 & -2.9 & 49.6 & 38.5 & 148 \\
\hline & Total government expenditure & 228.3 & 268.1 & 273.9 & 310.5 & 388.2 & 527.6 & 578 & 596.3 \\
\hline
\end{tabular}




\begin{tabular}{|c|c|c|c|c|c|c|c|c|c|}
\hline \multirow[t]{4}{*}{ Collective goods in cash } & Property income, consolidated & 16.3 & 18.2 & 22 & 21.5 & 23.2 & 26.7 & 37.6 & 44.7 \\
\hline & Other current transfers, consolidated & 4.3 & 8.5 & 47.5 & 82.8 & 131.8 & 125.4 & 120.1 & 123.3 \\
\hline & Capital transfers, consolidated & 13.9 & 5.4 & 1.4 & 1.7 & 1 & 3.6 & 4.8 & 9.5 \\
\hline & Total government expenditure & 34.5 & 32.1 & 70.9 & 106 & 156 & 155.7 & 162.5 & 177.5 \\
\hline \multirow[t]{3}{*}{ International co-operation } & Other current transfers, consolidated & 4.3 & 8.5 & 47.2 & 82.7 & 131.7 & 125.3 & 120 & 123.2 \\
\hline & Capital transfers, consolidated & 13.9 & 5.4 & 1.4 & 1.7 & 1 & 3.6 & 4.8 & 9.5 \\
\hline & Total government expenditure & 18.2 & 13.9 & 48.6 & 84.4 & 132.7 & 128.9 & 124.8 & 132.7 \\
\hline \multirow[t]{3}{*}{ General purpose and block grants } & Other current transfers, consolidated & 0 & 0 & 0.3 & 0.1 & 0.1 & 0.1 & 0.1 & 0.1 \\
\hline & Capital transfers, consolidated & 0 & 0 & 0 & 0 & 0 & 0 & 0 & 0 \\
\hline & Total government expenditure & 0 & 0 & 0.3 & 0.1 & 0.1 & 0.1 & 0.1 & 0.1 \\
\hline Interest & Property income, consolidated & 16.3 & 18.2 & 22 & 21.5 & 23.2 & 26.7 & 37.6 & 44.7 \\
\hline \multirow[t]{9}{*}{ Individual goods } & Compensation of employees & 451.1 & 499.6 & 557 & 630.3 & 710.2 & 858.9 & 1039.2 & 1048.5 \\
\hline & Intermediate consumption etc. & 251.8 & 290.9 & 320.8 & 350.6 & 400.2 & 456.1 & 527.9 & 490.7 \\
\hline & Subsidies & 76.1 & 75.1 & 76.8 & 83 & 114.5 & 137.5 & 161.4 & 137.4 \\
\hline & Property income, consolidated & 0 & 0 & 0 & 0 & 0 & 0 & 0 & 0 \\
\hline & Social benefits & 802.4 & 883.5 & 1026.5 & 1147.4 & 1329.9 & 1576.8 & 1960.8 & 2199 \\
\hline & Other current transfers, consolidated & 25.8 & 29.1 & 31.7 & 40 & 44 & 59.9 & 60.2 & 69.7 \\
\hline & Capital transfers, consolidated & 1.6 & 4.4 & 16.3 & 5.3 & 8.6 & 10.1 & 16.9 & 11.3 \\
\hline & Gross capital formation etc. & 165.4 & 161.5 & 155.9 & 201.1 & 298.6 & 332.7 & 404.9 & 245.7 \\
\hline & Total government expenditure & 1774.2 & 1944.1 & 2185 & 2457.7 & 2906 & 3432 & 4171.3 & 4202.3 \\
\hline \multirow[t]{9}{*}{ Individual goods in kind } & Compensation of employees & 451.1 & 499.6 & 557 & 630.3 & 710.2 & 858.9 & 1039.2 & 1048.5 \\
\hline & Intermediate consumption etc. & 251.8 & 290.9 & 320.8 & 350.6 & 400.2 & 456.1 & 527.9 & 490.7 \\
\hline & Subsidies & 76.1 & 75.1 & 76.8 & 83 & 114.5 & 137.5 & 161.4 & 137.4 \\
\hline & Property income, consolidated & 0 & 0 & 0 & 0 & 0 & 0 & 0 & 0 \\
\hline & Social benefits & 112.1 & 115.1 & 138.6 & 155 & 178.3 & 231.8 & 277.7 & 282.5 \\
\hline & Other current transfers, consolidated & 25.8 & 29.1 & 31.7 & 40 & 44 & 59.9 & 60.2 & 69.7 \\
\hline & Capital transfers, consolidated & 1.6 & 4.4 & 16.3 & 5.3 & 8.6 & 10.1 & 16.9 & 11.3 \\
\hline & Gross capital formation etc. & 165.4 & 161.5 & 155.9 & 201.1 & 298.6 & 332.7 & 404.9 & 245.7 \\
\hline & Total government expenditure & 1083.9 & 1175.7 & 1297.1 & 1465.3 & 1754.4 & 2087 & 2488.2 & 2285.8 \\
\hline \multirow[t]{8}{*}{ Health } & Compensation of employees & 105.7 & 120.7 & 132.3 & 160.8 & 180.8 & 226.1 & 273.2 & 259.1 \\
\hline & Intermediate consumption etc. & 80.2 & 90.7 & 106.7 & 113.3 & 126.9 & 153.4 & 183.9 & 177.4 \\
\hline & Property income, consolidated & 0 & 0 & 0 & 0 & 0 & 0 & 0 & 0 \\
\hline & Social benefits & 100.6 & 102.8 & 122.8 & 136.9 & 155.8 & 200.8 & 240 & 242.7 \\
\hline & Other current transfers, consolidated & 0.6 & 0.1 & 0.6 & 1.3 & 1.2 & 2.3 & 1.3 & 0.9 \\
\hline & Capital transfers, consolidated & 0 & 2.4 & 2.6 & 2.2 & 2.5 & 3.3 & 2.6 & 2.6 \\
\hline & Gross capital formation etc. & 31.3 & 31.6 & 14.9 & 25.5 & 70.5 & 81.2 & 108.1 & 65.9 \\
\hline & Total government expenditure & 318.4 & 348.3 & 379.9 & 440 & 537.7 & 667.1 & 809.1 & 748.6 \\
\hline \multirow{8}{*}{$\begin{array}{l}\text { Non-market recreation, culture and } \\
\text { religion }\end{array}$} & Compensation of employees & 38.4 & 42.5 & 49.2 & 54.5 & 63.6 & 75.8 & 88.1 & 81.8 \\
\hline & Intermediate consumption etc. & 31.8 & 36.5 & 44.5 & 53.4 & 60.7 & 68.3 & 75.9 & 64.2 \\
\hline & Property income, consolidated & 0 & 0 & 0 & 0 & 0 & 0 & 0 & 0 \\
\hline & Social benefits & 0 & 0 & 0 & 0 & 0 & 0 & 0.1 & 0 \\
\hline & Other current transfers, consolidated & 19.8 & 24.3 & 14.7 & 25.8 & 27.9 & 36.2 & 31.2 & 31.5 \\
\hline & Capital transfers, consolidated & 1.6 & 2 & 12.4 & 2.2 & 4.8 & 6.4 & 13.6 & 7.1 \\
\hline & Gross capital formation etc. & 33.7 & 35.5 & 48.7 & 70.1 & 74.9 & 64.8 & 86 & 57.6 \\
\hline & Total government expenditure & 125.3 & 140.8 & 169.5 & 206 & 231.9 & 251.5 & 294.9 & 242.2 \\
\hline \multirow[t]{8}{*}{ Education } & Compensation of employees & 273.2 & 298.7 & 333.7 & 368.4 & 406.5 & 477.7 & 571 & 546.1 \\
\hline & Intermediate consumption etc. & 118.2 & 136.4 & 147.9 & 158.4 & 184.3 & 204.9 & 232.5 & 212.6 \\
\hline & Property income, consolidated & 0 & 0 & 0 & 0 & 0 & 0 & 0 & 0 \\
\hline & Social benefits & 11.5 & 12.3 & 15.8 & 18.1 & 22.5 & 31 & 37.6 & 39.8 \\
\hline & Other current transfers, consolidated & 1.2 & 1.1 & 8.7 & 5 & 6.1 & 10.7 & 13.8 & 12.5 \\
\hline & Capital transfers, consolidated & 0 & 0 & 1.3 & 0.9 & 0.9 & 0.2 & 0.3 & 0.9 \\
\hline & Gross capital formation etc. & 96.1 & 90.2 & 84 & 101 & 141.4 & 171.1 & 198.1 & 108 \\
\hline & Total government expenditure & 500.2 & 538.7 & 591.4 & 651.8 & 761.7 & 895.6 & 1053.3 & 919.9 \\
\hline \multirow[t]{7}{*}{ Social services } & Compensation of employees & 33.8 & 37.7 & 41.8 & 46.6 & 59.3 & 79.3 & 106.9 & 161.5 \\
\hline & Intermediate consumption etc. & 21.6 & 27.3 & 21.7 & 25.5 & 28.3 & 29.5 & 35.6 & 36.5 \\
\hline & Property income, consolidated & 0 & 0 & 0 & 0 & 0 & 0 & 0 & 0 \\
\hline & Other current transfers, consolidated & 4.2 & 3.6 & 7.7 & 7.9 & 8.8 & 10.7 & 13.9 & 24.8 \\
\hline & Capital transfers, consolidated & 0 & 0 & 0 & 0 & 0.4 & 0.2 & 0.4 & 0.7 \\
\hline & Gross capital formation etc. & 4.3 & 4.2 & 8.3 & 4.5 & 11.8 & 15.6 & 12.7 & 14.2 \\
\hline & Total government expenditure & 63.9 & 72.8 & 79.5 & 84.5 & 108.6 & 135.3 & 169.5 & 237.7 \\
\hline Market subsidies & Subsidies & 76.1 & 75.1 & 76.8 & 83 & 114.5 & 137.5 & 161.4 & 137.4 \\
\hline Individual goods in cash & Social benefits & 690.3 & 768.4 & 887.9 & 992.4 & 1151.6 & 1345 & 1683.1 & 1916.5 \\
\hline \begin{tabular}{|l|} 
Social cash transfers \\
\end{tabular} & Social benefits & 690.3 & 768.4 & 887.9 & 992.4 & 1151.6 & 1345 & 1683.1 & 1916.5 \\
\hline
\end{tabular}




\begin{tabular}{|c|c|c|c|c|c|c|c|c|c|}
\hline \multicolumn{2}{|l|}{ Estonia-Central government } & \multicolumn{8}{|c|}{ Expenditures ( $m \ln E \boxminus K)$} \\
\hline COFOG Special & Transaction & 2002 & 2003 & 2004 & 2005 & 2006 & 2007 & 2008 & 2009 \\
\hline \multirow[t]{9}{*}{ Total } & Compensation of employees & 464.1 & 520.7 & 569.5 & 640.3 & 730.6 & 909.2 & 1081.9 & 1025 \\
\hline & Intermediate consumption etc. & 362.7 & 429 & 405.3 & 451.4 & 515.9 & 580.8 & 663 & 636.9 \\
\hline & Subsidies & 54.9 & 57.1 & 54.2 & 59.6 & 89.5 & 108.6 & 124.3 & 88.3 \\
\hline & Property income, consolidated & 10 & 11.4 & 14.5 & 13.5 & 13.2 & 11.7 & 15.5 & 28.8 \\
\hline & Social benefits & 618.5 & 679.8 & 791.2 & 883.4 & 1035.1 & 1210.7 & 1503 & 1635.5 \\
\hline & Other current transfers, consolidated & 267.9 & 288.2 & 344.2 & 432.6 & 506.7 & 553 & 593.8 & 583.4 \\
\hline & Capital transfers, consolidated & 68.1 & 68.4 & 75.2 & 58.5 & 153.4 & 207.5 & 236.4 & 118.7 \\
\hline & Gross capital formation etc. & 264.5 & 247.6 & 195.9 & 262.7 & 341.1 & 454.4 & 507.6 & 417 \\
\hline & Total government expenditure & 2110.7 & 2302.2 & 2450 & 2802 & 3385.5 & 4035.9 & 4725.5 & 4533.6 \\
\hline \multirow[t]{8}{*}{ Collective goods } & Compensation of employees & 285.2 & 325.9 & 358.5 & 399 & 447.9 & 563.1 & 666.6 & 603.3 \\
\hline & Intermediate consumption etc. & 246.4 & 297.7 & 261.4 & 297.1 & 339.4 & 383.2 & 435.3 & 425.5 \\
\hline & Property income, consolidated & 10 & 11.4 & 14.5 & 13.5 & 13.2 & 11.7 & 15.5 & 28.8 \\
\hline & Social benefits & 0 & 0 & 1.9 & 2.6 & 2.9 & 6.4 & 7.1 & 8.8 \\
\hline & Other current transfers, consolidated & 240.4 & 265.8 & 310.9 & 388.4 & 465.2 & 493.1 & 521.7 & 491.4 \\
\hline & Capital transfers, consolidated & 49.7 & 48.5 & 54 & 47.2 & 133.1 & 160.4 & 204.5 & 95.4 \\
\hline & Gross capital formation etc. & 173.3 & 148.1 & 135.5 & 188.5 & 235.9 & 326.6 & 317.2 & 306.7 \\
\hline & Total government expenditure & 1005 & 1097.4 & 1136.7 & 1336.3 & 1637.6 & 1944.5 & 2167.9 & 1959.9 \\
\hline \multirow[t]{8}{*}{ Collective goods in kind } & Compensation of employees & 285.2 & 325.9 & 358.5 & 399 & 447.9 & 563.1 & 666.6 & 603.3 \\
\hline & Intermediate consumption etc. & 246.4 & 297.7 & 261.4 & 297.1 & 339.4 & 383.2 & 435.3 & 425.5 \\
\hline & Property income, consolidated & 0 & 0 & 0 & 0 & 0 & 0 & 0 & 0 \\
\hline & Social benefits & 0 & 0 & 1.9 & 2.6 & 2.9 & 6.4 & 7.1 & 8.8 \\
\hline & Other current transfers, consolidated & 10.8 & 19.2 & 44.8 & 54.6 & 61.1 & 66 & 67.5 & 73.9 \\
\hline & Capital transfers, consolidated & 23.3 & 41.9 & 53.7 & 46.1 & 132.9 & 157.1 & 199.1 & 89.9 \\
\hline & Gross capital formation etc. & 173.3 & 148.1 & 135.5 & 188.5 & 235.9 & 326.6 & 317.2 & 306.7 \\
\hline & Total government expenditure & 739 & 832.8 & 855.8 & 987.9 & 1220.1 & 1502.4 & 1692.8 & 1508.1 \\
\hline \multirow[t]{8}{*}{ General governance services } & Compensation of employees & 56.6 & 70.7 & 72 & 76.1 & 83.9 & 104.7 & 121.1 & 107.5 \\
\hline & Intermediate consumption etc. & 62.2 & 62 & 56.3 & 53.2 & 57.9 & 58.1 & 70.9 & 67.9 \\
\hline & Property income, consolidated & 0 & 0 & 0 & 0 & 0 & 0 & 0 & 0 \\
\hline & Social benefits & 0 & 0 & 0.5 & 0 & 0 & 0.1 & 0.1 & 0.2 \\
\hline & Other current transfers, consolidated & 1 & 2.1 & 0.2 & 1.6 & 1.4 & 2.1 & 2 & 6.8 \\
\hline & Capital transfers, consolidated & 0 & 0 & 0 & 0 & 0 & 0 & 0.1 & 0.9 \\
\hline & Gross capital formation etc. & 56.1 & 38.4 & -21.2 & 1.9 & 11.3 & 54.1 & -48.1 & 14.9 \\
\hline & Total government expenditure & 175.9 & 173.2 & 107.8 & 132.8 & 154.5 & 219.1 & 146.1 & 198.2 \\
\hline \multirow[t]{8}{*}{ Basic research } & Compensation of employees & 9 & 10 & 10.7 & 10.8 & 13 & 14 & 17.6 & 17.5 \\
\hline & Intermediate consumption etc. & 4.5 & 5 & 5.2 & 5.7 & 7.1 & 6.9 & 8 & 7.4 \\
\hline & Property income, consolidated & 0 & 0 & 0 & 0 & 0 & 0 & 0 & 0 \\
\hline & Social benefits & 0 & 0 & 0.3 & 0.5 & 0.8 & 1.2 & 1.6 & 2 \\
\hline & Other current transfers, consolidated & 0.6 & 0.5 & 0 & 0.2 & 0 & 0.2 & 0 & 0.1 \\
\hline & Capital transfers, consolidated & 0 & 0 & 0 & 0 & 0 & 0 & 0 & 0.3 \\
\hline & Gross capital formation etc. & 0.2 & 0.3 & 5.6 & 3.5 & 6.4 & 10 & 15.4 & 12 \\
\hline & Total government expenditure & 14.3 & 15.8 & 21.8 & 20.7 & 27.3 & 32.3 & 42.6 & 39.3 \\
\hline Defence & Compensation of employees & 29.9 & 36.4 & 45.9 & 54.6 & 62 & 78.2 & 96 & 89.8 \\
\hline & Intermediate consumption etc. & 38.5 & 68.5 & 45.2 & 65.9 & 79.7 & 90.1 & 111.1 & 133.1 \\
\hline & Property income, consolidated & 0 & 0 & 0 & 0 & 0 & 0 & 0 & 0 \\
\hline & Social benefits & 0 & 0 & 0.8 & 0.9 & 1 & 3.3 & 3.1 & 3.1 \\
\hline & Other current transfers, consolidated & 0 & 0.2 & 0.6 & 0.7 & 0.9 & 1.6 & 0.7 & 0.4 \\
\hline & Capital transfers, consolidated & 0.3 & 0 & 0 & 0 & 0 & 0.8 & 0.9 & 0 \\
\hline & Gross capital formation etc. & 39.2 & 42.9 & 42.3 & 33.8 & 30.8 & 28.9 & 69.5 & 85.1 \\
\hline & Total government expenditure & 107.9 & 148 & 134.8 & 155.9 & 174.4 & 202.9 & 281.3 & 311.5 \\
\hline Public order and safety & Compensation of employees & 117.8 & 129.1 & 138.6 & 150 & 167 & 212.7 & 255.4 & 226.6 \\
\hline & Intermediate consumption etc. & 49.6 & 52.4 & 55.3 & 54.9 & 62 & 75.1 & 72.4 & 63.6 \\
\hline & Property income, consolidated & 0 & 0 & 0 & 0 & 0 & 0 & 0 & 0 \\
\hline & Social benefits & 0 & 0 & 0.1 & 0.1 & 0.1 & 0.1 & 0.1 & 0 \\
\hline & Other current transfers, consolidated & 0 & 0.2 & 1.4 & 2.3 & 1.8 & 1.8 & 1.2 & 1.6 \\
\hline & Capital transfers, consolidated & 0.5 & 0 & 0.1 & 0.1 & 0.3 & 0.2 & 0 & 1.4 \\
\hline & Gross capital formation etc. & 23.4 & 24.3 & 9 & 35.1 & 42.2 & 57.7 & 107.5 & 33.8 \\
\hline & Total government expenditure & 191.3 & 206 & 204.5 & 242.5 & 273.4 & 347.6 & 436.6 & 327 \\
\hline Infrastructure and spatial & Compensation of employees & 20.6 & 18.2 & 19.1 & 21.3 & 23.6 & 28.2 & 29.6 & 22.5 \\
\hline development & Intermediate consumption etc. & 26.6 & 41.2 & 32.2 & 37.6 & 41.2 & 44.5 & 51.3 & 50.8 \\
\hline & Property income, consolidated & 0 & 0 & 0 & 0 & 0 & 0 & 0 & 0 \\
\hline & Social benefits & 0 & 0 & 0 & 0 & 0 & 0 & 0 & 0 \\
\hline & Other current transfers, consolidated & 0 & 0 & 1.4 & 3.9 & 3.9 & 4.8 & 5.4 & 6.3 \\
\hline & Capital transfers, consolidated & 0 & 2.3 & 0.4 & 2.5 & 7.1 & 7.3 & 62.7 & 16.7 \\
\hline & Gross capital formation etc. & 40.3 & 27.6 & 84.7 & 106.2 & 145.7 & 141.3 & 136.1 & 132.4 \\
\hline & Total government expenditure & 87.5 & 89.3 & 137.8 & 171.5 & 221.5 & 226.1 & 285.1 & 228.7 \\
\hline Market regulation & Compensation of employees & 51.3 & 61.5 & 72.2 & 86.2 & 98.4 & 125.3 & 146.9 & 139.4 \\
\hline & Intermediate consumption etc. & 65 & 68.6 & 67.2 & 79.8 & 91.5 & 108.5 & 121.6 & 102.7 \\
\hline & Property income, consolidated & 0 & 0 & 0 & 0 & 0 & 0 & 0 & 0 \\
\hline & Social benefits & 0 & 0 & 0.2 & 1.1 & 1 & 1.7 & 2.2 & 3.5 \\
\hline & Other current transfers, consolidated & 9.2 & 16.2 & 41.2 & 45.9 & 53.1 & 55.5 & 58.2 & 58.7 \\
\hline & Capital transfers, consolidated & 22.5 & 39.6 & 53.2 & 43.5 & 125.5 & 148.8 & 135.4 & 70.6 \\
\hline & Gross capital formation etc. & 14.1 & 14.6 & 15.1 & 8 & -0.5 & 34.6 & 36.8 & 28.5 \\
\hline & Total government expenditure & 162.1 & 200.5 & 249.1 & 264.5 & 369 & 474.4 & 501.1 & 403.4 \\
\hline
\end{tabular}




\begin{tabular}{|c|c|c|c|c|c|c|c|c|c|}
\hline \multirow[t]{4}{*}{ Collective goods in cash } & Property income, consolidated & 10 & 11.4 & 14.5 & 13.5 & 13.2 & 11.7 & 15.5 & 28.8 \\
\hline & Other current transfers, consolidated & 229.6 & 246.6 & 266.1 & 333.8 & 404.1 & 427.1 & 454.2 & 417.5 \\
\hline & Capital transfers, consolidated & 26.4 & 6.6 & 0.3 & 1.1 & 0.2 & 3.3 & 5.4 & 5.5 \\
\hline & Total government expenditure & 266 & 264.6 & 280.9 & 348.4 & 417.5 & 442.1 & 475.1 & 451.8 \\
\hline \multirow[t]{3}{*}{ International co-operation } & Other current transfers, consolidated & 4.2 & 8.3 & 53.8 & 84 & 133.3 & 127.7 & 122.5 & 126.2 \\
\hline & Capital transfers, consolidated & 26.4 & 5.4 & 0.3 & 1.1 & 0.2 & 3.3 & 5.4 & 5.5 \\
\hline & Total government expenditure & 30.6 & 13.7 & 54.1 & 85.1 & 133.5 & 131 & 127.9 & 131.7 \\
\hline \multirow[t]{3}{*}{ General purpose and block grants } & Other current transfers, consolidated & 225.4 & 238.3 & 212.3 & 249.8 & 270.8 & 299.4 & 331.7 & 291.3 \\
\hline & Capital transfers, consolidated & 0 & 1.2 & 0 & 0 & 0 & 0 & 0 & 0 \\
\hline & Total government expenditure & 225.4 & 239.5 & 212.3 & 249.8 & 270.8 & 299.4 & 331.7 & 291.3 \\
\hline Interest & Property income, consolidated & 10 & 11.4 & 14.5 & 13.5 & 13.2 & 11.7 & 15.5 & 28.8 \\
\hline \multirow[t]{9}{*}{ Individual goods } & Compensation of employees & 178.9 & 194.8 & 211 & 241.3 & 282.7 & 346.1 & 415.3 & 421.7 \\
\hline & Intermediate consumption etc. & 116.3 & 131.3 & 143.9 & 154.3 & 176.5 & 197.6 & 227.7 & 211.4 \\
\hline & Subsidies & 54.9 & 57.1 & 54.2 & 59.6 & 89.5 & 108.6 & 124.3 & 88.3 \\
\hline & Property income, consolidated & 0 & 0 & 0 & 0 & 0 & 0 & 0 & 0 \\
\hline & Social benefits & 618.5 & 679.8 & 789.3 & 880.8 & 1032.2 & 1204.3 & 1495.9 & 1626.7 \\
\hline & Other current transfers, consolidated & 27.5 & 22.4 & 33.3 & 44.2 & 41.5 & 59.9 & 72.1 & 92 \\
\hline & Capital transfers, consolidated & 18.4 & 19.9 & 21.2 & 11.3 & 20.3 & 47.1 & 31.9 & 23.3 \\
\hline & Gross capital formation etc. & 91.2 & 99.5 & 60.4 & 74.2 & 105.2 & 127.8 & 190.4 & 110.3 \\
\hline & Total government expenditure & 1105.7 & 1204.8 & 1313.3 & 1465.7 & 1747.9 & 2091.4 & 2557.6 & 2573.7 \\
\hline \multirow[t]{9}{*}{ Individual goods in kind } & Compensation of employees & 178.9 & 194.8 & 211 & 241.3 & 282.7 & 346.1 & 415.3 & 421.7 \\
\hline & Intermediate consumption etc. & 116.3 & 131.3 & 143.9 & 154.3 & 176.5 & 197.6 & 227.7 & 211.4 \\
\hline & Subsidies & 54.9 & 57.1 & 54.2 & 59.6 & 89.5 & 108.6 & 124.3 & 88.3 \\
\hline & Property income, consolidated & 0 & 0 & 0 & 0 & 0 & 0 & 0 & 0 \\
\hline & Social benefits & 11 & 12.4 & 12.3 & 14.8 & 19.9 & 27.9 & 38.6 & 41.6 \\
\hline & Other current transfers, consolidated & 27.5 & 22.4 & 33.3 & 44.2 & 41.5 & 59.9 & 72.1 & 92 \\
\hline & Capital transfers, consolidated & 18.4 & 19.9 & 21.2 & 11.3 & 20.3 & 47.1 & 31.9 & 23.3 \\
\hline & Gross capital formation etc. & 91.2 & 99.5 & 60.4 & 74.2 & 105.2 & 127.8 & 190.4 & 110.3 \\
\hline & Total government expenditure & 498.2 & 537.4 & 536.3 & 599.7 & 735.6 & 915 & 1100.3 & 988.6 \\
\hline \multirow[t]{8}{*}{ Health } & Compensation of employees & 50.8 & 58.4 & 60.4 & 75.4 & 86.4 & 106.9 & 128 & 119.7 \\
\hline & Intermediate consumption etc. & 42.9 & 49.2 & 57.3 & 59.7 & 67.5 & 81.2 & 98.1 & 95.7 \\
\hline & Property income, consolidated & 0 & 0 & 0 & 0 & 0 & 0 & 0 & 0 \\
\hline & Social benefits & 3.1 & 3.1 & 2.6 & 3.8 & 5.9 & 7.4 & 13.2 & 14.8 \\
\hline & Other current transfers, consolidated & 8.9 & 7.4 & 7.4 & 11.4 & 12.2 & 16.4 & 20.3 & 20.2 \\
\hline & Capital transfers, consolidated & 0 & 0 & 0 & 0 & 0 & 16.3 & 0.5 & 1 \\
\hline & Gross capital formation etc. & 24.7 & 25.5 & 13.7 & 14 & 37.1 & 44.2 & 86.8 & 48.9 \\
\hline & Total government expenditure & 130.4 & 143.6 & 141.4 & 164.3 & 209.1 & 272.4 & 346.9 & 300.3 \\
\hline \multirow{8}{*}{$\begin{array}{l}\text { Non-market recreation, culture and } \\
\text { religion }\end{array}$} & Compensation of employees & 21.6 & 22.7 & 26.7 & 29.2 & 33.9 & 39.5 & 44.1 & 40.1 \\
\hline & Intermediate consumption etc. & 13.7 & 14.5 & 17.2 & 20.3 & 23.9 & 26.2 & 27.7 & 24.4 \\
\hline & Property income, consolidated & 0 & 0 & 0 & 0 & 0 & 0 & 0 & 0 \\
\hline & Social benefits & 0 & 0 & 0 & 0 & 0 & 0 & 0 & 0 \\
\hline & Other current transfers, consolidated & 13.6 & 12.5 & 10.4 & 16.5 & 16.3 & 20.6 & 14.9 & 19.9 \\
\hline & Capital transfers, consolidated & 7.4 & 8.9 & 19.1 & 10 & 13.6 & 18.2 & 17.4 & 8.7 \\
\hline & Gross capital formation etc. & 11.9 & 17.7 & 22.3 & 31.5 & 23 & 21.4 & 25.5 & 19 \\
\hline & Total government expenditure & 68.2 & 76.3 & 95.7 & 107.5 & 110.7 & 125.9 & 129.6 & 112.1 \\
\hline \multirow[t]{8}{*}{ Education } & Compensation of employees & 81.6 & 89.3 & 97.4 & 108.3 & 125.5 & 147.7 & 174.4 & 171.5 \\
\hline & Intermediate consumption etc. & 47.3 & 54.6 & 56.7 & 60.5 & 71.1 & 76.6 & 84.9 & 78.8 \\
\hline & Property income, consolidated & 0 & 0 & 0 & 0 & 0 & 0 & 0 & 0 \\
\hline & Social benefits & 7.9 & 9.3 & 9.7 & 11 & 14 & 20.5 & 25.4 & 26.8 \\
\hline & Other current transfers, consolidated & 0.8 & 0.3 & 7.8 & 7 & 2.6 & 10.4 & 14.9 & 15.7 \\
\hline & Capital transfers, consolidated & 11 & 11 & 2 & 1 & 6.3 & 12 & 13.1 & 7.5 \\
\hline & Gross capital formation etc. & 51.9 & 53.6 & 19 & 27.3 & 43.3 & 57 & 74.3 & 41.9 \\
\hline & Total government expenditure & 200.5 & 218.1 & 192.6 & 215.1 & 262.8 & 324.2 & 387 & 342.2 \\
\hline \multirow[t]{7}{*}{ Social services } & Compensation of employees & 24.9 & 24.4 & 26.5 & 28.4 & 36.9 & 52 & 68.8 & 90.4 \\
\hline & Intermediate consumption etc. & 12.4 & 13 & 12.7 & 13.8 & 14 & 13.6 & 17 & 12.5 \\
\hline & Property income, consolidated & 0 & 0 & 0 & 0 & 0 & 0 & 0 & 0 \\
\hline & Other current transfers, consolidated & 4.2 & 2.2 & 7.7 & 9.3 & 10.4 & 12.5 & 22 & 36.2 \\
\hline & Capital transfers, consolidated & 0 & 0 & 0.1 & 0.3 & 0.4 & 0.6 & 0.9 & 6.1 \\
\hline & Gross capital formation etc. & 2.7 & 2.7 & 5.4 & 1.4 & 1.8 & 5.2 & 3.8 & 0.5 \\
\hline & Total government expenditure & 44.2 & 42.3 & 52.4 & 53.2 & 63.5 & 83.9 & 112.5 & 145.7 \\
\hline Market subsidies & Subsidies & 54.9 & 57.1 & 54.2 & 59.6 & 89.5 & 108.6 & 124.3 & 88.3 \\
\hline Individual goods in cash & Social benefits & 607.5 & 667.4 & 777 & 866 & 1012.3 & 1176.4 & 1457.3 & 1585.1 \\
\hline Social cash transfers & Social benefits & 607.5 & 667.4 & 777 & 866 & 1012.3 & 1176.4 & 1457.3 & 1585.1 \\
\hline
\end{tabular}




\begin{tabular}{|c|c|c|c|c|c|c|c|c|c|}
\hline \multicolumn{2}{|l|}{ Estonia-Local government } & \multicolumn{8}{|c|}{ Expenditures ( $\mathrm{m} \ln$ E円K) } \\
\hline COFOG Special & Transaction & 2002 & 2003 & 2004 & 2005 & 2006 & 2007 & 2008 & 2009 \\
\hline \multirow[t]{9}{*}{ Total } & Compensation of employees & 331.4 & 362.9 & 410.2 & 458.2 & 506.8 & 610.5 & 735.8 & 702.8 \\
\hline & Intermediate consumption etc. & 233.8 & 259.6 & 277.8 & 324.1 & 361.2 & 417.6 & 480.8 & 422.7 \\
\hline & Subsidies & 21.2 & 18 & 22.7 & 23.4 & 25.1 & 29 & 37.1 & 48.5 \\
\hline & Property income, consolidated & 8 & 7.5 & 8.1 & 8.4 & 10.4 & 15.2 & 24.2 & 18.5 \\
\hline & Social benefits & 34.6 & 36.7 & 38.8 & 47.3 & 48.9 & 50.2 & 57.7 & 63.3 \\
\hline & Other current transfers, consolidated & 13.7 & 25.3 & 30.9 & 39.6 & 38.7 & 53.1 & 56.4 & 46.5 \\
\hline & Capital transfers, consolidated & 9.9 & 0.8 & 9.2 & 11.7 & 22.5 & 29.2 & 41.9 & 27.4 \\
\hline & Gross capital formation etc. & 151 & 124.9 & 129.8 & 145.3 & 230 & 322.8 & 341.8 & 248.6 \\
\hline & Total government expenditure & 803.6 & 835.7 & 927.5 & 1058 & 1243.6 & 1527.6 & 1775.7 & 1578.3 \\
\hline \multirow[t]{8}{*}{ Collective goods } & Compensation of employees & 62.2 & 63.1 & 69.6 & 74.5 & 84.3 & 104.3 & 124.2 & 121.3 \\
\hline & Intermediate consumption etc. & 100.8 & 102.6 & 102.9 & 130.3 & 140.2 & 161.8 & 183.2 & 153.5 \\
\hline & Property income, consolidated & 8 & 7.5 & 8.1 & 8.4 & 10.4 & 15.2 & 24.2 & 18.5 \\
\hline & Social benefits & 0 & 0 & 0 & 0.1 & 0.5 & 0.6 & 0.7 & 0.6 \\
\hline & Other current transfers, consolidated & 5.8 & 12.5 & 10.8 & 15.2 & 10.8 & 14.3 & 13.8 & 12.4 \\
\hline & Capital transfers, consolidated & 9.9 & 0.8 & 6.5 & 9.4 & 18 & 25 & 35.8 & 24.2 \\
\hline & Gross capital formation etc. & 77.1 & 63.3 & 35.2 & 18.8 & 37.1 & 118.1 & 128 & 114.8 \\
\hline & Total government expenditure & 263.8 & 249.8 & 233.1 & 256.7 & 301.3 & 439.3 & 509.9 & 445.3 \\
\hline \multirow[t]{8}{*}{ Collective goods in kind } & Compensation of employees & 62.2 & 63.1 & 69.6 & 74.5 & 84.3 & 104.3 & 124.2 & 121.3 \\
\hline & Intermediate consumption etc. & 100.8 & 102.6 & 102.9 & 130.3 & 140.2 & 161.8 & 183.2 & 153.5 \\
\hline & Property income, consolidated & 0 & 0 & 0 & 0 & 0 & 0 & 0 & 0 \\
\hline & Social benefits & 0 & 0 & 0 & 0.1 & 0.5 & 0.6 & 0.7 & 0.6 \\
\hline & Other current transfers, consolidated & 5.3 & 10 & 9.8 & 14.2 & 10 & 13.5 & 12.8 & 11 \\
\hline & Capital transfers, consolidated & 0 & 0.8 & 4.9 & 8.5 & 17 & 24.7 & 32.4 & 20.2 \\
\hline & Gross capital formation etc. & 77.1 & 63.3 & 35.2 & 18.8 & 37.1 & 118.1 & 128 & 114.8 \\
\hline & Total government expenditure & 245.4 & 239.8 & 222.4 & 246.4 & 289.1 & 423 & 481.3 & 421.4 \\
\hline \multirow[t]{8}{*}{ General governance services } & Compensation of employees & 41.7 & 36 & 42.8 & 48.8 & 56.5 & 68.1 & 80.4 & 76.9 \\
\hline & Intermediate consumption etc. & 22 & 24.8 & 21 & 23.3 & 26.5 & 31.9 & 33.3 & 27 \\
\hline & Property income, consolidated & 0 & 0 & 0 & 0 & 0 & 0 & 0 & 0 \\
\hline & Social benefits & 0 & 0 & 0 & 0.1 & 0.1 & 0 & 0 & 0 \\
\hline & Other current transfers, consolidated & 0.4 & 0.6 & 1.4 & 1.6 & 2.4 & 3.7 & 2.3 & 2.4 \\
\hline & Capital transfers, consolidated & 0 & 0 & 0 & 0 & 0.2 & 0.1 & 0 & 0 \\
\hline & Gross capital formation etc. & 4.6 & 4.3 & -1.6 & -14.8 & -5.1 & -26.2 & -1.1 & -6.3 \\
\hline & Total government expenditure & 68.7 & 65.7 & 63.6 & 59 & 80.6 & 77.6 & 114.9 & 100 \\
\hline \multirow[t]{8}{*}{ Basic research } & Compensation of employees & 0 & 0 & 0 & 0 & 0.1 & 0.1 & 0.1 & 0.1 \\
\hline & Intermediate consumption etc. & 0 & 0 & 0 & 0 & 0 & 0 & 0 & 0 \\
\hline & Property income, consolidated & 0 & 0 & 0 & 0 & 0 & 0 & 0 & 0 \\
\hline & Social benefits & 0 & 0 & 0 & 0 & 0 & 0 & 0 & 0 \\
\hline & Other current transfers, consolidated & 0 & 0 & 0 & 0 & 0 & 0 & 0 & 0 \\
\hline & Capital transfers, consolidated & 0 & 0 & 0 & 0 & 0 & 0 & 0 & 0 \\
\hline & Gross capital formation etc. & 0 & 0 & 0 & 0 & 0 & 0 & 0 & 0 \\
\hline & Total government expenditure & 0 & 0 & 0 & 0 & 0.1 & 0.1 & 0.1 & 0.1 \\
\hline Defence & Compensation of employees & 0 & 0 & 0 & 0 & 0 & 0 & 0 & 0 \\
\hline & Intermediate consumption etc. & 0 & 0 & 0 & 0 & 0 & 0 & 0 & 0 \\
\hline & Property income, consolidated & 0 & 0 & 0 & 0 & 0 & 0 & 0 & 0 \\
\hline & Social benefits & 0 & 0 & 0 & 0 & 0 & 0 & 0 & 0 \\
\hline & Other current transfers, consolidated & 0 & 0 & 0 & 0 & 0 & 0 & 0 & 0 \\
\hline & Capital transfers, consolidated & 0 & 0 & 0 & 0 & 0 & 0 & 0 & 0 \\
\hline & Gross capital formation etc. & 0 & 0 & 0 & 0 & 0.9 & 0 & 0 & 0 \\
\hline & Total government expenditure & 0 & 0 & 0 & 0 & 0.9 & 0 & 0 & 0 \\
\hline \begin{tabular}{|l|} 
Public order and safety \\
\end{tabular} & Compensation of employees & 4 & 4.1 & 4.8 & 0.4 & 0.4 & 1.4 & 2.2 & 3.3 \\
\hline & Intermediate consumption etc. & 2.1 & 2.4 & 2 & 0.9 & 1.3 & 1.9 & 2.2 & 1.6 \\
\hline & Property income, consolidated & 0 & 0 & 0 & 0 & 0 & 0 & 0 & 0 \\
\hline & Social benefits & 0 & 0 & 0 & 0 & 0 & 0 & 0 & 0 \\
\hline & Other current transfers, consolidated & 0 & 0 & 0.6 & 1.2 & 1.3 & 0.9 & 0.9 & 0.5 \\
\hline & Capital transfers, consolidated & 0 & 0 & 0 & 1 & 0.4 & 0 & 0.1 & 0 \\
\hline & Gross capital formation etc. & 0.3 & 0.2 & 0.5 & -2.5 & 1.2 & 0.3 & 0.5 & 1.5 \\
\hline & Total government expenditure & 6.4 & 6.7 & 7.9 & 1 & 4.6 & 4.5 & 5.9 & 6.9 \\
\hline Infrastructure and spatial & Compensation of employees & 4 & 5.7 & 5.6 & 5.7 & 6.6 & 7.8 & 9.1 & 9.5 \\
\hline development & Intermediate consumption etc. & 40.7 & 41 & 41.7 & 52 & 59.5 & 72.4 & 84.3 & 66.8 \\
\hline & Property income, consolidated & 0 & 0 & 0 & 0 & 0 & 0 & 0 & 0 \\
\hline & Social benefits & 0 & 0 & 0 & 0 & 0 & 0.1 & 0.2 & 0.1 \\
\hline & Other current transfers, consolidated & 0 & 0 & 5.7 & 8.6 & 2.1 & 2.9 & 2.9 & 4.4 \\
\hline & Capital transfers, consolidated & 0 & 0 & 1.4 & 4.9 & 13.5 & 16 & 25.4 & 15.9 \\
\hline & Gross capital formation etc. & 48.1 & 39.2 & 29.8 & 34.2 & 42.2 & 129.1 & 127.2 & 0.1 \\
\hline & Total government expenditure & 92.8 & 85.9 & 84.2 & 105.4 & 123.9 & 228.3 & 249.1 & 96.8 \\
\hline \begin{tabular}{|l|} 
Market regulation \\
\end{tabular} & Compensation of employees & 12.5 & 17.3 & 16.4 & 19.6 & 20.7 & 26.9 & 32.4 & 31.5 \\
\hline & Intermediate consumption etc. & 36 & 34.4 & 38.2 & 54.1 & 52.9 & 55.6 & 63.4 & 58.1 \\
\hline & Property income, consolidated & 0 & 0 & 0 & 0 & 0 & 0 & 0 & 0 \\
\hline & Social benefits & 0 & 0 & 0 & 0 & 0.4 & 0.5 & 0.5 & 0.5 \\
\hline & Other current transfers, consolidated & 4.9 & 9.4 & 2.1 & 2.8 & 4.2 & 6 & 6.7 & 3.7 \\
\hline & Capital transfers, consolidated & 0 & 0.8 & 3.5 & 2.6 & 2.9 & 8.6 & 6.9 & 4.3 \\
\hline & Gross capital formation etc. & 24.1 & 19.6 & 6.5 & 1.9 & -2.1 & 14.9 & 1.4 & 119.5 \\
\hline & Total government expenditure & 77.5 & 81.5 & 66.7 & 81 & 79 & 112.5 & 111.3 & 217.6 \\
\hline
\end{tabular}




\begin{tabular}{|c|c|c|c|c|c|c|c|c|c|}
\hline \multirow[t]{4}{*}{ Collective goods in cash } & Property income, consolidated & 8 & 7.5 & 8.1 & 8.4 & 10.4 & 15.2 & 24.2 & 18.5 \\
\hline & Other current transfers, consolidated & 0.5 & 2.5 & 1 & 1 & 0.8 & 0.8 & 1 & 1.4 \\
\hline & Capital transfers, consolidated & 9.9 & 0 & 1.6 & 0.9 & 1 & 0.3 & 3.4 & 4 \\
\hline & Total government expenditure & 18.4 & 10 & 10.7 & 10.3 & 12.2 & 16.3 & 28.6 & 23.9 \\
\hline \multirow[t]{3}{*}{ International co-operation } & Other current transfers, consolidated & 0 & 0.2 & 0.7 & 1 & 0.7 & 0.7 & 0.9 & 1.3 \\
\hline & Capital transfers, consolidated & 9.9 & 0 & 1.6 & 0.9 & 1 & 0.3 & 3.4 & 4 \\
\hline & Total government expenditure & 9.9 & 0.2 & 2.3 & 1.9 & 1.7 & 1 & 4.3 & 5.3 \\
\hline \multirow[t]{3}{*}{ General purpose and block grants } & Other current transfers, consolidated & 0.5 & 2.3 & 0.3 & 0 & 0.1 & 0.1 & 0.1 & 0.1 \\
\hline & Capital transfers, consolidated & 0 & 0 & 0 & 0 & 0 & 0 & 0 & 0 \\
\hline & Total government expenditure & 0.5 & 2.3 & 0.3 & 0 & 0.1 & 0.1 & 0.1 & 0.1 \\
\hline Interest & Property income, consolidated & 8 & 7.5 & 8.1 & 8.4 & 10.4 & 15.2 & 24.2 & 18.5 \\
\hline \multirow{9}{*}{ Individual goods } & Compensation of employees & 269.2 & 299.8 & 340.6 & 383.7 & 422.5 & 506.2 & 611.6 & 581.5 \\
\hline & Intermediate consumption etc. & 133 & 157 & 174.9 & 193.8 & 221 & 255.8 & 297.6 & 269.2 \\
\hline & Subsidies & 21.2 & 18 & 22.7 & 23.4 & 25.1 & 29 & 37.1 & 48.5 \\
\hline & Property income, consolidated & 0 & 0 & 0 & 0 & 0 & 0 & 0 & 0 \\
\hline & Social benefits & 34.6 & 36.7 & 38.8 & 47.2 & 48.4 & 49.6 & 57 & 62.7 \\
\hline & Other current transfers, consolidated & 7.9 & 12.8 & 20.1 & 24.4 & 27.9 & 38.8 & 42.6 & 34.1 \\
\hline & Capital transfers, consolidated & 0 & 0 & 2.7 & 2.3 & 4.5 & 4.2 & 6.1 & 3.2 \\
\hline & Gross capital formation etc. & 73.9 & 61.6 & 94.6 & 126.5 & 192.9 & 204.7 & 213.8 & 133.8 \\
\hline & Total government expenditure & 539.8 & 585.9 & 694.4 & 801.3 & 942.3 & 1088.3 & 1265.8 & 1133 \\
\hline \multirow[t]{9}{*}{ Individual goods in kind } & Compensation of employees & 269.2 & 299.8 & 340.6 & 383.7 & 422.5 & 506.2 & 611.6 & 581.5 \\
\hline & Intermediate consumption etc. & 133 & 157 & 174.9 & 193.8 & 221 & 255.8 & 297.6 & 269.2 \\
\hline & Subsidies & 21.2 & 18 & 22.7 & 23.4 & 25.1 & 29 & 37.1 & 48.5 \\
\hline & Property income, consolidated & 0 & 0 & 0 & 0 & 0 & 0 & 0 & 0 \\
\hline & Social benefits & 4.1 & 3.5 & 8.5 & 9.4 & 11.5 & 14.1 & 16.6 & 17.1 \\
\hline & Other current transfers, consolidated & 7.9 & 12.8 & 20.1 & 24.4 & 27.9 & 38.8 & 42.6 & 34.1 \\
\hline & Capital transfers, consolidated & 0 & 0 & 2.7 & 2.3 & 4.5 & 4.2 & 6.1 & 3.2 \\
\hline & Gross capital formation etc. & 73.9 & 61.6 & 94.6 & 126.5 & 192.9 & 204.7 & 213.8 & 133.8 \\
\hline & Total government expenditure & 509.3 & 552.7 & 664.1 & 763.5 & 905.4 & 1052.8 & 1225.4 & 1087.4 \\
\hline \multirow[t]{8}{*}{ Health } & Compensation of employees & 52.2 & 59.7 & 69 & 82.1 & 91.2 & 115.4 & 140.4 & 134.7 \\
\hline & Intermediate consumption etc. & 35.1 & 39.2 & 47.8 & 51.5 & 57.3 & 70 & 83.6 & 79.7 \\
\hline & Property income, consolidated & 0 & 0 & 0 & 0 & 0 & 0 & 0 & 0 \\
\hline & Social benefits & 0.5 & 0.6 & 2.3 & 2.3 & 3 & 3.5 & 4.4 & 3.9 \\
\hline & Other current transfers, consolidated & 1.2 & 0.2 & 0.3 & 0.8 & 0.9 & 1.1 & 1 & 0.6 \\
\hline & Capital transfers, consolidated & 0 & 0 & 0.7 & 0 & 0 & 0 & 0 & 0 \\
\hline & Gross capital formation etc. & 6.6 & 6 & 0.7 & 11.1 & 33 & 36.7 & 20.6 & 16.7 \\
\hline & Total government expenditure & 95.6 & 105.7 & 120.8 & 147.8 & 185.4 & 226.7 & 250 & 235.6 \\
\hline \multirow{8}{*}{$\begin{array}{l}\text { Non-market recreation, culture and } \\
\text { religion }\end{array}$} & Compensation of employees & 16.7 & 19.8 & 22.5 & 25.3 & 29.7 & 36.2 & 43.9 & 41.8 \\
\hline & Intermediate consumption etc. & 18.1 & 22 & 27.4 & 33 & 36.9 & 42.1 & 48.3 & 39.7 \\
\hline & Property income, consolidated & 0 & 0 & 0 & 0 & 0 & 0 & 0 & 0 \\
\hline & Social benefits & 0 & 0 & 0 & 0 & 0 & 0 & 0.1 & 0 \\
\hline & Other current transfers, consolidated & 6.2 & 11.8 & 8.6 & 15 & 17.3 & 22.3 & 24.1 & 17.8 \\
\hline & Capital transfers, consolidated & 0 & 0 & 0.6 & 0.7 & 2.9 & 1.7 & 5.3 & 2.8 \\
\hline & Gross capital formation etc. & 21.7 & 17.8 & 26.3 & 38.6 & 51.9 & 43.4 & 60.5 & 38.6 \\
\hline & Total government expenditure & 62.7 & 71.4 & 85.4 & 112.6 & 138.7 & 145.7 & 182.2 & 140.7 \\
\hline \multirow[t]{8}{*}{ Education } & Compensation of employees & 191.7 & 209.3 & 236.5 & 260.1 & 281 & 330.2 & 396.6 & 374.5 \\
\hline & Intermediate consumption etc. & 70.9 & 81.7 & 90.9 & 98 & 113.2 & 128.4 & 147.6 & 133.8 \\
\hline & Property income, consolidated & 0 & 0 & 0 & 0 & 0 & 0 & 0 & 0 \\
\hline & Social benefits & 3.6 & 2.9 & 6.2 & 7.1 & 8.5 & 10.6 & 12.1 & 13.2 \\
\hline & Other current transfers, consolidated & 0.5 & 0.8 & 8.4 & 4.7 & 5.4 & 10.1 & 11 & 9.2 \\
\hline & Capital transfers, consolidated & 0 & 0 & 1.4 & 1.4 & 1.2 & 2.3 & 0.5 & 0.4 \\
\hline & Gross capital formation etc. & 44.1 & 36.5 & 64.8 & 73.7 & 98.1 & 114.1 & 123.8 & 66.1 \\
\hline & Total government expenditure & 310.8 & 331.2 & 408.2 & 445 & 507.4 & 595.7 & 691.6 & 597.2 \\
\hline \multirow[t]{7}{*}{ Social services } & Compensation of employees & 8.6 & 11 & 12.6 & 16.2 & 20.6 & 24.4 & 30.7 & 30.5 \\
\hline & Intermediate consumption etc. & 8.9 & 14.1 & 8.8 & 11.3 & 13.6 & 15.3 & 18.1 & 16 \\
\hline & Property income, consolidated & 0 & 0 & 0 & 0 & 0 & 0 & 0 & 0 \\
\hline & Other current transfers, consolidated & 0 & 0 & 2.8 & 3.9 & 4.3 & 5.3 & 6.5 & 6.5 \\
\hline & Capital transfers, consolidated & 0 & 0 & 0 & 0.2 & 0.4 & 0.2 & 0.3 & 0 \\
\hline & Gross capital formation etc. & 1.5 & 1.3 & 2.8 & 3.1 & 9.9 & 10.5 & 8.9 & 12.4 \\
\hline & Total government expenditure & 19 & 26.4 & 27 & 34.7 & 48.8 & 55.7 & 64.5 & 65.4 \\
\hline \begin{tabular}{|l|} 
Market subsidies \\
\end{tabular} & Subsidies & 21.2 & 18 & 22.7 & 23.4 & 25.1 & 29 & 37.1 & 48.5 \\
\hline Individual goods in cash & Social benefits & 30.5 & 33.2 & 30.3 & 37.8 & 36.9 & 35.5 & 40.4 & 45.6 \\
\hline \begin{tabular}{|l} 
Social cash transfers \\
\end{tabular} & Social benefits & 30.5 & 33.2 & 30.3 & 37.8 & 36.9 & 35.5 & 40.4 & 45.6 \\
\hline
\end{tabular}




\begin{tabular}{|c|c|c|c|c|c|c|c|c|c|}
\hline \multicolumn{2}{|l|}{ Estonia-Social security funds } & \multicolumn{8}{|c|}{ Expenditures $(m \ln \boxplus K)$} \\
\hline COFOG Special & Transaction & 2002 & 2003 & 2004 & 2005 & 2006 & 2007 & 2008 & 2009 \\
\hline \multirow[t]{9}{*}{ Total } & Compensation of employees & 2.8 & 5.2 & 5.7 & 5.5 & 5.1 & 6.7 & 12.1 & 45.1 \\
\hline & Intermediate consumption etc. & 3 & 2.9 & 2.5 & 3.1 & 3.4 & 3.2 & 3.2 & 10.8 \\
\hline & Subsidies & 0 & 0 & 0 & 0 & 0 & 0 & 0 & 0.7 \\
\hline & Property income, consolidated & 0 & 0 & 0 & 0 & 0 & 0 & 0 & 0 \\
\hline & Social benefits & 149.4 & 167.1 & 198.5 & 219.3 & 249.2 & 322.9 & 407.9 & 509.8 \\
\hline & Other current transfers, consolidated & 147.6 & 176 & 196.6 & 225.2 & 252.9 & 321.8 & 396 & 399.2 \\
\hline & Capital transfers, consolidated & 0 & 6.9 & 7.9 & 9.1 & 10.3 & 13.1 & 10.7 & 10.6 \\
\hline & Gross capital formation etc. & 0.1 & 0.1 & 0.4 & 0.5 & 0.4 & 0.4 & 0.8 & 1.6 \\
\hline & Total government expenditure & 302.9 & 358.2 & 411.6 & 462.7 & 521.3 & 668.1 & 830.7 & 977.8 \\
\hline \multirow[t]{8}{*}{ Collective goods } & Compensation of employees & 0 & 0 & 0 & 0 & 0 & 0 & 0 & 0 \\
\hline & Intermediate consumption etc. & 0.4 & 0.4 & 0.6 & 0.6 & 0.7 & 0.5 & 0.5 & 0.8 \\
\hline & Property income, consolidated & 0 & 0 & 0 & 0 & 0 & 0 & 0 & 0 \\
\hline & Social benefits & 0 & 0 & 0 & 0 & 0 & 0 & 0 & 0 \\
\hline & Other current transfers, consolidated & 0 & 0 & 0.8 & 0.8 & 0.1 & 0.1 & 0.1 & 0.2 \\
\hline & Capital transfers, consolidated & 0 & 0 & 0 & 0 & 0 & 0 & 0 & 0 \\
\hline & Gross capital formation etc. & 0 & 0 & 0 & 0 & 0 & 0 & 0 & 0 \\
\hline & Total government expenditure & 0.4 & 0.4 & 1.4 & 1.4 & 0.8 & 0.6 & 0.6 & 1 \\
\hline \multirow[t]{8}{*}{ Collective goods in kind } & Compensation of employees & 0 & 0 & 0 & 0 & 0 & 0 & 0 & 0 \\
\hline & Intermediate consumption etc. & 0.4 & 0.4 & 0.6 & 0.6 & 0.7 & 0.5 & 0.5 & 0.8 \\
\hline & Property income, consolidated & 0 & 0 & 0 & 0 & 0 & 0 & 0 & 0 \\
\hline & Social benefits & 0 & 0 & 0 & 0 & 0 & 0 & 0 & 0 \\
\hline & Other current transfers, consolidated & 0 & 0 & 0.8 & 0.8 & 0.1 & 0.1 & 0.1 & 0.2 \\
\hline & Capital transfers, consolidated & 0 & 0 & 0 & 0 & 0 & 0 & 0 & 0 \\
\hline & Gross capital formation etc. & 0 & 0 & 0 & 0 & 0 & 0 & 0 & 0 \\
\hline & Total government expenditure & 0.4 & 0.4 & 1.4 & 1.4 & 0.8 & 0.6 & 0.6 & 1 \\
\hline \multirow[t]{8}{*}{ General governance services } & Compensation of employees & 0 & 0 & 0 & 0 & 0 & 0 & 0 & 0 \\
\hline & Intermediate consumption etc. & 0.4 & 0.4 & 0.6 & 0.6 & 0.7 & 0.5 & 0.5 & 0.8 \\
\hline & Property income, consolidated & 0 & 0 & 0 & 0 & 0 & 0 & 0 & 0 \\
\hline & Social benefits & 0 & 0 & 0 & 0 & 0 & 0 & 0 & 0 \\
\hline & Other current transfers, consolidated & 0 & 0 & 0 & 0.1 & 0.1 & 0.1 & 0.1 & 0.2 \\
\hline & Capital transfers, consolidated & 0 & 0 & 0 & 0 & 0 & 0 & 0 & 0 \\
\hline & Gross capital formation etc. & 0 & 0 & 0 & 0 & 0 & 0 & 0 & 0 \\
\hline & Total government expenditure & 0.4 & 0.4 & 0.6 & 0.7 & 0.8 & 0.6 & 0.6 & 1 \\
\hline \multirow[t]{8}{*}{ Basic research } & Compensation of employees & 0 & 0 & 0 & 0 & 0 & 0 & 0 & 0 \\
\hline & Intermediate consumption etc. & 0 & 0 & 0 & 0 & 0 & 0 & 0 & 0 \\
\hline & Property income, consolidated & 0 & 0 & 0 & 0 & 0 & 0 & 0 & 0 \\
\hline & Social benefits & 0 & 0 & 0 & 0 & 0 & 0 & 0 & 0 \\
\hline & Other current transfers, consolidated & 0 & 0 & 0 & 0 & 0 & 0 & 0 & 0 \\
\hline & Capital transfers, consolidated & 0 & 0 & 0 & 0 & 0 & 0 & 0 & 0 \\
\hline & Gross capital formation etc. & 0 & 0 & 0 & 0 & 0 & 0 & 0 & 0 \\
\hline & Total government expenditure & 0 & 0 & 0 & 0 & 0 & 0 & 0 & 0 \\
\hline \begin{tabular}{|l} 
Defence \\
\end{tabular} & Compensation of employees & 0 & 0 & 0 & 0 & 0 & 0 & 0 & 0 \\
\hline & Intermediate consumption etc. & 0 & 0 & 0 & 0 & 0 & 0 & 0 & 0 \\
\hline & Property income, consolidated & 0 & 0 & 0 & 0 & 0 & 0 & 0 & 0 \\
\hline & Social benefits & 0 & 0 & 0 & 0 & 0 & 0 & 0 & 0 \\
\hline & Other current transfers, consolidated & 0 & 0 & 0 & 0 & 0 & 0 & 0 & 0 \\
\hline & Capital transfers, consolidated & 0 & 0 & 0 & 0 & 0 & 0 & 0 & 0 \\
\hline & Gross capital formation etc. & 0 & 0 & 0 & 0 & 0 & 0 & 0 & 0 \\
\hline & Total government expenditure & 0 & 0 & 0 & 0 & 0 & 0 & 0 & 0 \\
\hline \begin{tabular}{|l} 
Public order and safety \\
\end{tabular} & Compensation of employees & 0 & 0 & 0 & 0 & 0 & 0 & 0 & 0 \\
\hline & Intermediate consumption etc. & 0 & 0 & 0 & 0 & 0 & 0 & 0 & 0 \\
\hline & Property income, consolidated & 0 & 0 & 0 & 0 & 0 & 0 & 0 & 0 \\
\hline & Social benefits & 0 & 0 & 0 & 0 & 0 & 0 & 0 & 0 \\
\hline & Other current transfers, consolidated & 0 & 0 & 0 & 0 & 0 & 0 & 0 & 0 \\
\hline & Capital transfers, consolidated & 0 & 0 & 0 & 0 & 0 & 0 & 0 & 0 \\
\hline & Gross capital formation etc. & 0 & 0 & 0 & 0 & 0 & 0 & 0 & 0 \\
\hline & Total government expenditure & 0 & 0 & 0 & 0 & 0 & 0 & 0 & 0 \\
\hline Infrastructure and spatial & Compensation of employees & 0 & 0 & 0 & 0 & 0 & 0 & 0 & 0 \\
\hline development & Intermediate consumption etc. & 0 & 0 & 0 & 0 & 0 & 0 & 0 & 0 \\
\hline & Property income, consolidated & 0 & 0 & 0 & 0 & 0 & 0 & 0 & 0 \\
\hline & Social benefits & 0 & 0 & 0 & 0 & 0 & 0 & 0 & 0 \\
\hline & Other current transfers, consolidated & 0 & 0 & 0 & 0 & 0 & 0 & 0 & 0 \\
\hline & Capital transfers, consolidated & 0 & 0 & 0 & 0 & 0 & 0 & 0 & 0 \\
\hline & Gross capital formation etc. & 0 & 0 & 0 & 0 & 0 & 0 & 0 & 0 \\
\hline & Total government expenditure & 0 & 0 & 0 & 0 & 0 & 0 & 0 & 0 \\
\hline \begin{tabular}{|l|} 
Market regulation \\
\end{tabular} & Compensation of employees & 0 & 0 & 0 & 0 & 0 & 0 & 0 & 0 \\
\hline & Intermediate consumption etc. & 0 & 0 & 0 & 0 & 0 & 0 & 0 & 0 \\
\hline & Property income, consolidated & 0 & 0 & 0 & 0 & 0 & 0 & 0 & 0 \\
\hline & Social benefits & 0 & 0 & 0 & 0 & 0 & 0 & 0 & 0 \\
\hline & Other current transfers, consolidated & 0 & 0 & 0.8 & 0.7 & 0 & 0 & 0 & 0 \\
\hline & Capital transfers, consolidated & 0 & 0 & 0 & 0 & 0 & 0 & 0 & 0 \\
\hline & Gross capital formation etc. & 0 & 0 & 0 & 0 & 0 & 0 & 0 & 0 \\
\hline & Total government expenditure & 0 & 0 & 0.8 & 0.7 & 0 & 0 & 0 & 0 \\
\hline
\end{tabular}




\begin{tabular}{|c|c|c|c|c|c|c|c|c|c|}
\hline \multirow[t]{4}{*}{ Collective goods in cash } & Property income, consolidated & 0 & 0 & 0 & 0 & 0 & 0 & 0 & 0 \\
\hline & Other current transfers, consolidated & 0 & 0 & 0 & 0 & 0 & 0 & 0 & 0 \\
\hline & Capital transfers, consolidated & 0 & 0 & 0 & 0 & 0 & 0 & 0 & 0 \\
\hline & Total government expenditure & 0 & 0 & 0 & 0 & 0 & 0 & 0 & 0 \\
\hline \multirow[t]{3}{*}{ International co-operation } & Other current transfers, consolidated & 0 & 0 & 0 & 0 & 0 & 0 & 0 & 0 \\
\hline & Capital transfers, consolidated & 0 & 0 & 0 & 0 & 0 & 0 & 0 & 0 \\
\hline & Total government expenditure & 0 & 0 & 0 & 0 & 0 & 0 & 0 & 0 \\
\hline \multirow[t]{3}{*}{ General purpose and block grants } & Other current transfers, consolidated & 0 & 0 & 0 & 0 & 0 & 0 & 0 & 0 \\
\hline & Capital transfers, consolidated & 0 & 0 & 0 & 0 & 0 & 0 & 0 & 0 \\
\hline & Total government expenditure & 0 & 0 & 0 & 0 & 0 & 0 & 0 & 0 \\
\hline Interest & Property income, consolidated & 0 & 0 & 0 & 0 & 0 & 0 & 0 & 0 \\
\hline \multirow[t]{9}{*}{ Individual goods } & Compensation of employees & 2.8 & 5.2 & 5.7 & 5.5 & 5.1 & 6.7 & 12.1 & 45.1 \\
\hline & Intermediate consumption etc. & 2.6 & 2.5 & 1.9 & 2.5 & 2.7 & 2.7 & 2.7 & 10 \\
\hline & Subsidies & 0 & 0 & 0 & 0 & 0 & 0 & 0 & 0.7 \\
\hline & Property income, consolidated & 0 & 0 & 0 & 0 & 0 & 0 & 0 & 0 \\
\hline & Social benefits & 149.4 & 167.1 & 198.5 & 219.3 & 249.2 & 322.9 & 407.9 & 509.8 \\
\hline & Other current transfers, consolidated & 147.6 & 176 & 195.8 & 224.4 & 252.8 & 321.7 & 395.9 & 399 \\
\hline & Capital transfers, consolidated & 0 & 6.9 & 7.9 & 9.1 & 10.3 & 13.1 & 10.7 & 10.6 \\
\hline & Gross capital formation etc. & 0.1 & 0.1 & 0.4 & 0.5 & 0.4 & 0.4 & 0.8 & 1.6 \\
\hline & Total government expenditure & 302.5 & 357.8 & 410.2 & 461.3 & 520.5 & 667.5 & 830.1 & 976.8 \\
\hline \multirow{9}{*}{ Individual goods in kind } & Compensation of employees & 2.8 & 5.2 & 5.7 & 5.5 & 5.1 & 6.7 & 12.1 & 45.1 \\
\hline & Intermediate consumption etc. & 2.6 & 2.5 & 1.9 & 2.5 & 2.7 & 2.7 & 2.7 & 10 \\
\hline & Subsidies & 0 & 0 & 0 & 0 & 0 & 0 & 0 & 0.7 \\
\hline & Property income, consolidated & 0 & 0 & 0 & 0 & 0 & 0 & 0 & 0 \\
\hline & Social benefits & 97 & 99.2 & 117.8 & 130.7 & 146.8 & 189.9 & 222.5 & 224 \\
\hline & Other current transfers, consolidated & 147.6 & 176 & 195.8 & 224.4 & 252.8 & 321.7 & 395.9 & 399 \\
\hline & Capital transfers, consolidated & 0 & 6.9 & 7.9 & 9.1 & 10.3 & 13.1 & 10.7 & 10.6 \\
\hline & Gross capital formation etc. & 0.1 & 0.1 & 0.4 & 0.5 & 0.4 & 0.4 & 0.8 & 1.6 \\
\hline & Total government expenditure & 250.1 & 289.9 & 329.5 & 372.7 & 418.1 & 534.5 & 644.7 & 691 \\
\hline \multirow[t]{8}{*}{ Health } & Compensation of employees & 2.7 & 2.8 & 2.9 & 3.2 & 3.3 & 3.9 & 4.7 & 4.5 \\
\hline & Intermediate consumption etc. & 2.3 & 2.2 & 1.7 & 2.1 & 2.2 & 2.1 & 2.2 & 2 \\
\hline & Property income, consolidated & 0 & 0 & 0 & 0 & 0 & 0 & 0 & 0 \\
\hline & Social benefits & 97 & 99.2 & 117.8 & 130.7 & 146.8 & 189.9 & 222.5 & 224 \\
\hline & Other current transfers, consolidated & 147.6 & 174.5 & 193.6 & 222.7 & 251.8 & 320.2 & 391.6 & 385 \\
\hline & Capital transfers, consolidated & 0 & 6.9 & 7.9 & 9.1 & 10.3 & 13.1 & 10.7 & 10.6 \\
\hline & Gross capital formation etc. & 0.1 & 0.1 & 0.4 & 0.5 & 0.4 & 0.4 & 0.8 & 0.3 \\
\hline & Total government expenditure & 249.7 & 285.7 & 324.3 & 368.3 & 414.8 & 529.6 & 632.5 & 626.4 \\
\hline \multirow{8}{*}{$\begin{array}{l}\text { Non-market recreation, culture and } \\
\text { religion }\end{array}$} & Compensation of employees & 0 & 0 & 0 & 0 & 0 & 0 & 0 & 0 \\
\hline & Intermediate consumption etc. & 0 & 0 & 0 & 0 & 0 & 0 & 0 & 0 \\
\hline & Property income, consolidated & 0 & 0 & 0 & 0 & 0 & 0 & 0 & 0 \\
\hline & Social benefits & 0 & 0 & 0 & 0 & 0 & 0 & 0 & 0 \\
\hline & Other current transfers, consolidated & 0 & 0 & 0 & 0 & 0 & 0 & 0 & 0 \\
\hline & Capital transfers, consolidated & 0 & 0 & 0 & 0 & 0 & 0 & 0 & 0 \\
\hline & Gross capital formation etc. & 0 & 0 & 0 & 0 & 0 & 0 & 0 & 0 \\
\hline & Total government expenditure & 0 & 0 & 0 & 0 & 0 & 0 & 0 & 0 \\
\hline \multirow[t]{8}{*}{ Education } & Compensation of employees & 0 & 0 & 0 & 0 & 0 & 0 & 0 & 0 \\
\hline & Intermediate consumption etc. & 0 & 0 & 0 & 0 & 0 & 0 & 0 & 0 \\
\hline & Property income, consolidated & 0 & 0 & 0 & 0 & 0 & 0 & 0 & 0 \\
\hline & Social benefits & 0 & 0 & 0 & 0 & 0 & 0 & 0 & 0 \\
\hline & Other current transfers, consolidated & 0 & 0 & 0 & 0 & 0 & 0 & 0 & 0 \\
\hline & Capital transfers, consolidated & 0 & 0 & 0 & 0 & 0 & 0 & 0 & 0 \\
\hline & Gross capital formation etc. & 0 & 0 & 0 & 0 & 0 & 0 & 0 & 0 \\
\hline & Total government expenditure & 0 & 0 & 0 & 0 & 0 & 0 & 0 & 0 \\
\hline \multirow[t]{7}{*}{ Social services } & Compensation of employees & 0.1 & 2.4 & 2.8 & 2.3 & 1.8 & 2.8 & 7.4 & 40.6 \\
\hline & Intermediate consumption etc. & 0.3 & 0.3 & 0.2 & 0.4 & 0.5 & 0.6 & 0.5 & 8 \\
\hline & Property income, consolidated & 0 & 0 & 0 & 0 & 0 & 0 & 0 & 0 \\
\hline & Other current transfers, consolidated & 0 & 1.5 & 2.2 & 1.7 & 1 & 1.5 & 4.3 & 14 \\
\hline & Capital transfers, consolidated & 0 & 0 & 0 & 0 & 0 & 0 & 0 & 0 \\
\hline & Gross capital formation etc. & 0 & 0 & 0 & 0 & 0 & 0 & 0 & 1.3 \\
\hline & Total government expenditure & 0.4 & 4.2 & 5.2 & 4.4 & 3.3 & 4.9 & 12.2 & 63.9 \\
\hline Market subsidies & Subsidies & 0 & 0 & 0 & 0 & 0 & 0 & 0 & 0.7 \\
\hline Individual goods in cash & Social benefits & 52.4 & 67.9 & 80.7 & 88.6 & 102.4 & 133 & 185.4 & 285.8 \\
\hline Social cash transfers & Social benefits & 52.4 & 67.9 & 80.7 & 88.6 & 102.4 & 133 & 185.4 & 285.8 \\
\hline
\end{tabular}




\begin{tabular}{|l|c|c|c|c|c|}
\hline Estonia-General government & \multicolumn{4}{|c|}{ Em ployment (full time equivalents in thousands) } \\
\hline \multicolumn{1}{|c|}{ Cofog-Special } & $\mathbf{2 0 0 5}$ & $\mathbf{2 0 0 6}$ & $\mathbf{2 0 0 7}$ & $\mathbf{2 0 0 8}$ & $\mathbf{2 0 0 9}$ \\
\hline Total & 121.3 & 122.2 & 121.7 & 122.4 & 120.9 \\
Collective goods in kind & 41.2 & 41.7 & 41.2 & 41.7 & 41.3 \\
General governance services & 9.8 & 10.0 & 9.9 & 10.1 & 9.5 \\
Basic research & 0.8 & 0.9 & 0.8 & 0.8 & 0.8 \\
Defence & 3.7 & 4.2 & 3.8 & 4.4 & 4.9 \\
Public order and safety & 13.9 & 13.5 & 13.1 & 12.9 & 13.1 \\
Infrastructure and spatial development & 2.6 & 2.7 & 2.7 & 2.5 & 2.1 \\
Market regulation & 10.4 & 10.4 & 11.0 & 11.1 & 10.8 \\
Individual goods in kind & 80.1 & 80.6 & 80.5 & 80.6 & 79.6 \\
Health & 18.2 & 18.3 & 18.5 & 18.9 & 18.5 \\
Non-market recreation, culture and religion & 7.1 & 7.6 & 7.6 & 7.3 & 7.2 \\
Education & 49.5 & 49.3 & 48.8 & 48.8 & 48.0 \\
Social services & 5.3 & 5.5 & 5.5 & 5.6 & 5.9 \\
\hline
\end{tabular}

\begin{tabular}{|l|c|c|c|c|c|}
\hline Estonia-Central government & \multicolumn{4}{|c|}{ Em ployment (full time equivalents in thousands) } \\
\hline \multicolumn{1}{|c|}{ Cofog-Special } & $\mathbf{2 0 0 5}$ & $\mathbf{2 0 0 6}$ & $\mathbf{2 0 0 7}$ & $\mathbf{2 0 0 8}$ & $\mathbf{2 0 0 9}$ \\
\hline Total & 58.0 & 58.7 & 58.5 & 58.5 & 57.3 \\
Collective goods in kind & 33.9 & 34.2 & 33.5 & 33.8 & 33.2 \\
General governance services & 5.7 & 5.7 & 5.6 & 5.7 & 5.2 \\
Basic research & 0.8 & 0.9 & 0.7 & 0.8 & 0.8 \\
Defence & 3.7 & 4.2 & 3.8 & 4.4 & 4.9 \\
Public order and safety & 13.9 & 13.5 & 13.0 & 12.7 & 12.9 \\
Infrastructure and spatial development & 1.8 & 1.8 & 1.8 & 1.7 & 1.3 \\
Market regulation & 7.9 & 8.1 & 8.5 & 8.5 & 8.2 \\
Individual goods in kind & 24.1 & 24.5 & 24.9 & 24.7 & 24.1 \\
Health & 8.1 & 8.2 & 8.4 & 8.3 & 8.1 \\
Non-market recreation, culture and religion & 3.0 & 3.2 & 3.2 & 2.9 & 2.8 \\
Education & 10.4 & 10.5 & 10.6 & 11.0 & 10.6 \\
Social services & 2.6 & 2.6 & 2.7 & 2.5 & 2.6 \\
\hline
\end{tabular}




\section{Revenues}

\begin{tabular}{|c|c|c|c|c|c|c|c|c|}
\hline Estonia-General government & & & & Revenue & $n$ In EEK) & & & \\
\hline Kinds of Revenues & 2002 & 2003 & 2004 & 2005 & 2006 & 2007 & 2008 & 2009 \\
\hline Taxes & 1558.6 & 1759.3 & 1936.4 & 2242.1 & 2708 & 3307.7 & 3224.3 & 3107.5 \\
\hline Indirect taxes & 972.2 & 1057.8 & 1167.1 & 1460.3 & 1761.9 & 2111 & 1947.2 & 2062.6 \\
\hline Direct taxes & 586.4 & 701.6 & 769.3 & 781.8 & 946.1 & 1196.7 & 1277.1 & 1044.9 \\
\hline Capital taxes & - & - & - & - & - & - & - & - \\
\hline Social contributions & 859.1 & 930.2 & 1011.4 & 1157.7 & 1365.5 & 1699.3 & 1911.8 & 1842.4 \\
\hline Other revenues & - & - & - & - & - & - & - & - \\
\hline Sales and fees & - & - & - & - & - & - & - & - \\
\hline Property income & 94 & 108.3 & 123.8 & 122.8 & 170.5 & 236.4 & 242.5 & 319.9 \\
\hline Total revenues & 2802.4 & 3181.4 & 3451 & 3937.8 & 4827.3 & 5846.1 & 5962.3 & 6016.7 \\
\hline
\end{tabular}

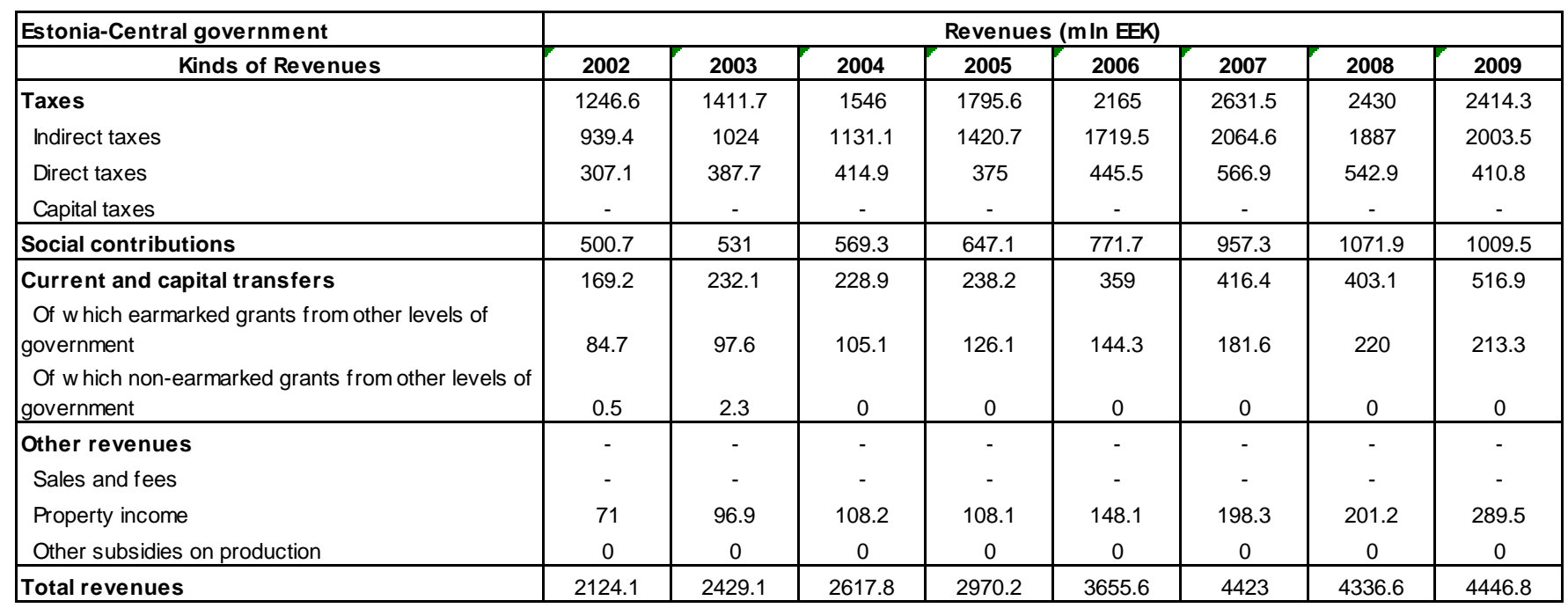

\begin{tabular}{|c|c|c|c|c|c|c|c|c|}
\hline \multirow{2}{*}{\begin{tabular}{|r|} 
Estonia-Social security funds \\
Kinds of Revenues \\
\end{tabular}} & \multicolumn{8}{|c|}{ Revenues (m In EEK) } \\
\hline & 2002 & 2003 & 2004 & 2005 & 2006 & 2007 & 2008 & 2009 \\
\hline Taxes & 0 & 0 & 0 & 0 & 0 & 0 & 0 & 0 \\
\hline Indirect taxes & 0 & 0 & 0 & 0 & 0 & 0 & 0 & 0 \\
\hline Direct taxes & 0 & 0 & 0 & 0 & 0 & 0 & 0 & 0 \\
\hline Capital taxes & - & - & - & - & - & - & - & - \\
\hline Social contributions & 358.4 & 399.2 & 442.1 & 510.6 & 593.9 & 741.9 & 839.9 & 832.9 \\
\hline $\begin{array}{l}\text { Of w hich earmarked grants from other levels of } \\
\text { government }\end{array}$ & 0 & 0 & 0.1 & 0.1 & 0.2 & 2 & 10.6 & 24.3 \\
\hline $\begin{array}{l}\text { Of w hich non-earmarked grants from other levels of } \\
\text { government }\end{array}$ & 0 & 0 & 0 & 0 & 0 & 0 & 0 & 0 \\
\hline Other revenues & - & - & - & - & - & - & - & - \\
\hline Sales and fees & - & - & - & - & - & - & - & - \\
\hline Property income & 2 & 1.1 & 2.5 & 1.6 & 4.7 & 13.4 & 17.1 & 10.7 \\
\hline Other subsidies on production & 0 & 0 & 0 & 0 & 0 & 0 & 0 & 0 \\
\hline Total revenues & 360.4 & 400.3 & 445.3 & 514.4 & 600.9 & 759.3 & 869.9 & 884.8 \\
\hline
\end{tabular}


Annex V -- Classification of expenses by function of government

\begin{tabular}{|c|c|c|c|}
\hline 01 & General public services & 06 & Housing and community amenities \\
\hline 011 & $\begin{array}{l}\text { Executive and legislative organs, financial } \\
\text { and fiscal affairs, external affairs }\end{array}$ & 061 & Housing development \\
\hline 012 & Foreign economic aid & 062 & Community development \\
\hline 013 & General services & 063 & Water supply \\
\hline 014 & Basic research & 064 & Street lighting \\
\hline 015 & R\&D General public services & 065 & R\&D Housing and community amenities \\
\hline 016 & General public services n.e.c. & 066 & Housing and community amenities n.e.c. \\
\hline 017 & Public debt transactions & 07 & Health \\
\hline 018 & $\begin{array}{l}\text { Transfers of a general character between } \\
\text { different levels of government }\end{array}$ & 071 & Medical products, appliances and equipment \\
\hline 02 & Defense & 072 & Outpatient service \\
\hline 021 & Military defense & 073 & Hospital services \\
\hline 022 & Civil defense & 074 & Public health services \\
\hline 023 & Foreign military aid & 075 & R\&D Health \\
\hline 024 & R\&D Defense & 076 & Health n.e.c. \\
\hline 025 & Defense n.e.c. & 08 & Recreation, culture and religion \\
\hline 03 & Public order and safety & 081 & Recreational and sporting services \\
\hline 031 & Police services & 082 & Cultural services \\
\hline 032 & Fire protection services & 083 & Broadcasting and publishing services \\
\hline 033 & Law courts & 084 & Religious and other community services \\
\hline 034 & Prisons & 085 & $R \& D$ Recreation, culture and relition \\
\hline 035 & R\&D Public order and safety & 086 & Recreation, culture and religion n.e.c. \\
\hline 036 & Public order and safety n.e.c. & 09 & Education \\
\hline 04 & Economic affairs & 091 & Pre-primary and primary education \\
\hline 041 & $\begin{array}{l}\text { General economic, commercial and labor } \\
\text { affairs }\end{array}$ & 092 & Secondary education \\
\hline 042 & Agriculture, forestry, Fishing and hunting & 093 & Postsecondary nontertiary education \\
\hline 043 & Fuel and energy & 094 & Tertiary education \\
\hline 044 & Mining, manufacturing and construction & 095 & Education not definable by level \\
\hline 045 & Transport & 096 & Subsidiary services to education \\
\hline 046 & Communication & 097 & R\&D Education \\
\hline 047 & Other industries & 098 & Education n.e.c. \\
\hline 048 & R\&D Economic affairs & 10 & Social protection \\
\hline 049 & Economic affairs n.e.c. & 101 & Sickness and disability \\
\hline 05 & Environmental protection & 102 & Old age \\
\hline 051 & Waste management & 103 & Survivors \\
\hline 052 & Waste water management & 104 & Family and children \\
\hline 053 & Pollution abatement & 105 & Unemployment \\
\hline 054 & Protection of biodiversity and landscape & 106 & Housing \\
\hline 055 & R\&D Environmental protection & 107 & Social exclusion n.e.c. \\
\hline \multirow[t]{2}{*}{056} & Environnemental protection n.e.c. & 108 & $R \& D$ Social protection \\
\hline & & 109 & Social protection n.e.c. \\
\hline
\end{tabular}

$\mathrm{R} \& \mathrm{D}=$ Research and Development

n.e.c. $=$ not elsewhere classified 